(C) 2022, The Authors. Published by Elsevier Inc. and Fass Inc. on behalf of the American Dairy Science Association ${ }^{\circledR}$. This is an open access article under the CC BY license (http://creativecommons.org/licenses/by/4.0/).

\title{
Temporal profiles describing markers of inflammation and metabolism during the transition period of pasture-based, seasonal-calving dairy cows
}

\author{
O. K. Spaans, ${ }^{1 *} \odot$ B. Kuhn-Sherlock, ${ }^{1} \odot$ A. Hickey, ${ }^{2}$ M. A. Crookenden, ${ }^{3} \odot$ A. Heiser, ${ }^{3} \odot$ C. R. Burke, ${ }^{1} \odot$ \\ C. V. C. Phyn, ${ }^{1}$ () and J. R. Roche ${ }^{2}$ () \\ ${ }^{1}$ DairyNZ Limited, Private Bag 3221, Hamilton, New Zealand 3240 \\ ${ }^{2}$ School of Biological Sciences, University of Auckland, Private Bag 92019, Auckland, New Zealand 1142 \\ ${ }^{3}$ AgResearch, Hopkirk Research Institute, Grasslands Research Centre, Palmerston North, New Zealand 4442
}

\begin{abstract}
The physiology of the dairy cow while transitioning from pregnancy to lactation is complex, with multifactorial processes studied extensively for the role they play in manifestation of disease along with associated economic losses and compromised animal welfare. Manuscripts outlining associations among nutrition, production, physiology, and genetics variables and transition cow disorders are common in literature, with blood analytes that are central to energy metabolism (e.g., nonesterified fatty acids; NEFA, $\beta$-hydroxybutyrate; BHB) often reported. Immunity and inflammation have increasingly been explored in the pathogenesis and persistence of disorders, with cytokines and acute phase proteins well documented. However, most of these studies have involved cows fed total mixed rations, which may not always reflect profiles of blood analytes and other physiological indicators of transition cow health in grazing cows consuming fresh pasture. Considering the comparatively lesser characterization of these analytes and markers in pasture-based, seasonal-calving dairy cows, we compiled a database consisting of 2,610 cow lactations that span $20 \mathrm{yr}$ of transition cow research in New Zealand. Using this database, analyte profiles from approximately $28 \mathrm{~d}$ precalving to $35 \mathrm{~d}$ postcalving were identified in dairy cows with a range of genetics, milk production potentials, and pasture-based farm management systems. These profiles characterize changes in energy reserves and metabolism (NEFA, BHB, glucose, insulin, growth hormone, insulin-like growth factor-1, leptin, body condition score, body weight), liver function (globulin, aspartate aminotransferase, glutamate dehydrogenase, gamma-glutamyl transpeptidase, bilirubin, cholesterol, liver triacylglycerides), protein metabolism (albumin, total protein, albumin:globulin ratio, creatinine, urea, creatine kinase), mineral balance (calcium,
\end{abstract}

Received June 16, 2021.

Accepted November 7, 2021.

*Corresponding author: olivia.spaans@dairynz.co.nz magnesium, phosphate, potassium, sodium, chloride, bicarbonate), inflammation (IL-1 $\beta$, IL-6, haptoglobin, reactive oxygen species, total antioxidant capacity), and uterine health (polymorphonuclear cells, macrophage cells, vaginal discharge score). Temporal changes are generally consistent with previously characterized homeorhetic changes experienced by the dairy cow during the transition from pregnancy to lactation in both pastoral and housed systems. Some of the profiles had not previously been presented for pastoral systems, or in some cases, presented for either system. Our results indicate that moderate-yielding dairy cows undergo similar homeorhetic changes to high-yielding housed cows; however, differences in diet composition result in greater $\mathrm{BHB}$ concentrations than expected, based on their milk production and NEFA concentrations. In addition, most cows were able to transition to a state of higher energy requirement following calving, albeit with an increased metabolic challenge in the liver, and only a small percentage of cows were classified with severe hepatic lipidosis or severe hyperketonemia. Increases in metabolic function of the liver were accompanied by changes in indicators of the immune system and changes in mineral balance that, combined, probably reflect the innate response to the transition from gestation to lactation.

Key words: reference intervals, grazing, physiology, peripartum

\section{INTRODUCTION}

The transition period in dairy cows, often defined as $3 \mathrm{wk}$ precalving to $3 \mathrm{wk}$ postcalving, is characterized by marked physiological and immunological changes that facilitate the metabolically challenging shift from gestation to lactation (Bauman and Currie, 1980; Bell, 1995; Sordillo et al., 2009). Complex metabolic and neuroendocrine interactions facilitate the directing of nutrients and energy to lactogenic pathways; for example, increased lipolysis of adipose tissues associated with increased concentrations of growth hormone 
(GH), which is facilitated by the uncoupling of the somatotropic axis (Ingvartsen, 2006; Lucy et al., 2009). These homeorhetic processes support the considerable increase in nutrient provision for lactogenesis, which typically surpasses nutrient intake during early lactation and results in a negative energy balance (NEB) as well as a negative protein and mineral balance. The NEB is commonly observed as a loss in BW and BCS, as adipose tissue reserves are mobilized to support lactation (Roche et al., 2009a, 2013a).

Physiological imbalances experienced during the periparturient period are central to the development of metabolic and infectious diseases (Ingvartsen, 2006). These disorders can have negative effects on reproduction and milk yield, with economic and animal welfare repercussions (Ospina et al., 2010a; McArt et al., 2013b). Therefore, much transition cow research has been devoted to exploring relationships between homeorhetic processes and metabolic or infectious diseases, with recent research focused more on inflammatory pathways activated during the establishment of these disorders (Heiser et al., 2015; Crookenden et al., 2019; Bradford and Swartz, 2020).

Blood analytes central to pathways of energy metabolism, liver function, protein metabolism, and inflammation are commonly measured and used to determine the effects of interventions on peripartum adaptation. Most transition cow research, however, has been undertaken in high-yielding housed dairy cows consuming a TMR. Fewer studies have focused on physiological changes in pasture-fed, moderate-yielding dairy cows managed in seasonal calving systems. Profiles of commonly measured analytes derived from studies of TMR-fed cows may not quantitatively or qualitatively reflect profiles in pasture-fed cows. Key differences in the metabolism of cows fed a TMR compared with pasture-fed cows have been identified, whereby the level of NFC consumed influences nutrient partitioning between body reserves and milk production (Kolver et al., 2006; Roche et al., 2006a). For example, diet manipulation shortened the time to recoupling of the somatotropic axis, which was apparent in changes in plasma GH, insulin, and IGF-1 concentrations during early lactation, and resulted in a less severe loss of BCS following calving (Kolver et al., 2006; Roche et al., 2006a).

The primary objective of this study was to describe the temporal profiles of humoral metabolites, uterine health indicators, BCS, and BW of pasture-based, seasonally calving dairy cows. A database of detailed transition cow research conducted within pasture-based, seasonal calving systems was compiled to characterize the profile of change in humoral factors during the transition period. This enabled robust profiling of analytes measured during the transition period across a range of cow genetics and milk production potentials, and under pasture-based farm management systems.

\section{MATERIALS AND METHODS}

\section{Database Establishment}

Previous experimental studies $(\mathrm{n}=20)$ undertaken by DairyNZ that were conducted between 2000 and 2018, during the transition period, and included measurements of blood analytes were used for the pooled analysis. A brief description of the experimental objective and treatments, along with the number of cow records in each data set, is provided in Table 1. All experiments were designed to manipulate aspects of pasture-based seasonal-calving management systems including milking frequency, pre- and postcalving nutrition, and transition cow management, with a total of 85 experiment by treatment combinations included. A brief outline of experiment design elements including details of the treatments examined is provided in Supplementary Material Appendix I (https://zenodo .org/record/5646637\#.YZz1n9DMKUk; Spaans et al., 2021).

Temporal measures of metabolites, minerals, cytokines, hormones, liver enzymes, acute phase proteins, BW, BCS, uterine health measures, and reproductive outcomes were collated into a large database of 2,610 complete cow lactations. Cow-lactation data were not included if there were missing blood analyte data for the entire experimental period in which they were enrolled $(\mathrm{n}=17)$, missing treatment and reproduction data ( $\mathrm{n}$ $=1$ ), cows removed before the end of the experiment in which they were enrolled $(\mathrm{n}=5)$, or incomplete or incorrect treatments during the experiment in which they were enrolled $(\mathrm{n}=3)$. Breeds represented were Holstein-Friesian $(\mathbf{H F} ; \mathrm{n}=1,811)$, Holstein-Friesian $\times$ Jersey crossbred $(\mathbf{H F} \times \mathbf{J} ; \mathrm{n}=350)$, and Jersey $(\mathbf{J} ; \mathrm{n}$ $=26$ ), with 423 cows of unknown breed. A summary of the number of observations for each variable by experiment is presented in Supplementary Table S1 (https:// zenodo.org/record/5646637\#.YZz1n9DMKUk; Spaans et al., 2021). Reproductive outcomes are not described in this study.

\section{Experimental Design, Herd, and Pasture Management}

The Ruakura Animal Ethics Committee (Hamilton, New Zealand) approved all animal manipulations in accordance with the New Zealand Animal Welfare Act (Ministry for Primary Industries, 1999) for all experiments included in the database. For each of the experiments, BCS were measured on a 1- to 10-point 
Spaans et al.: TEMPORAL PROFILES IN GRAZING DAIRY COWS

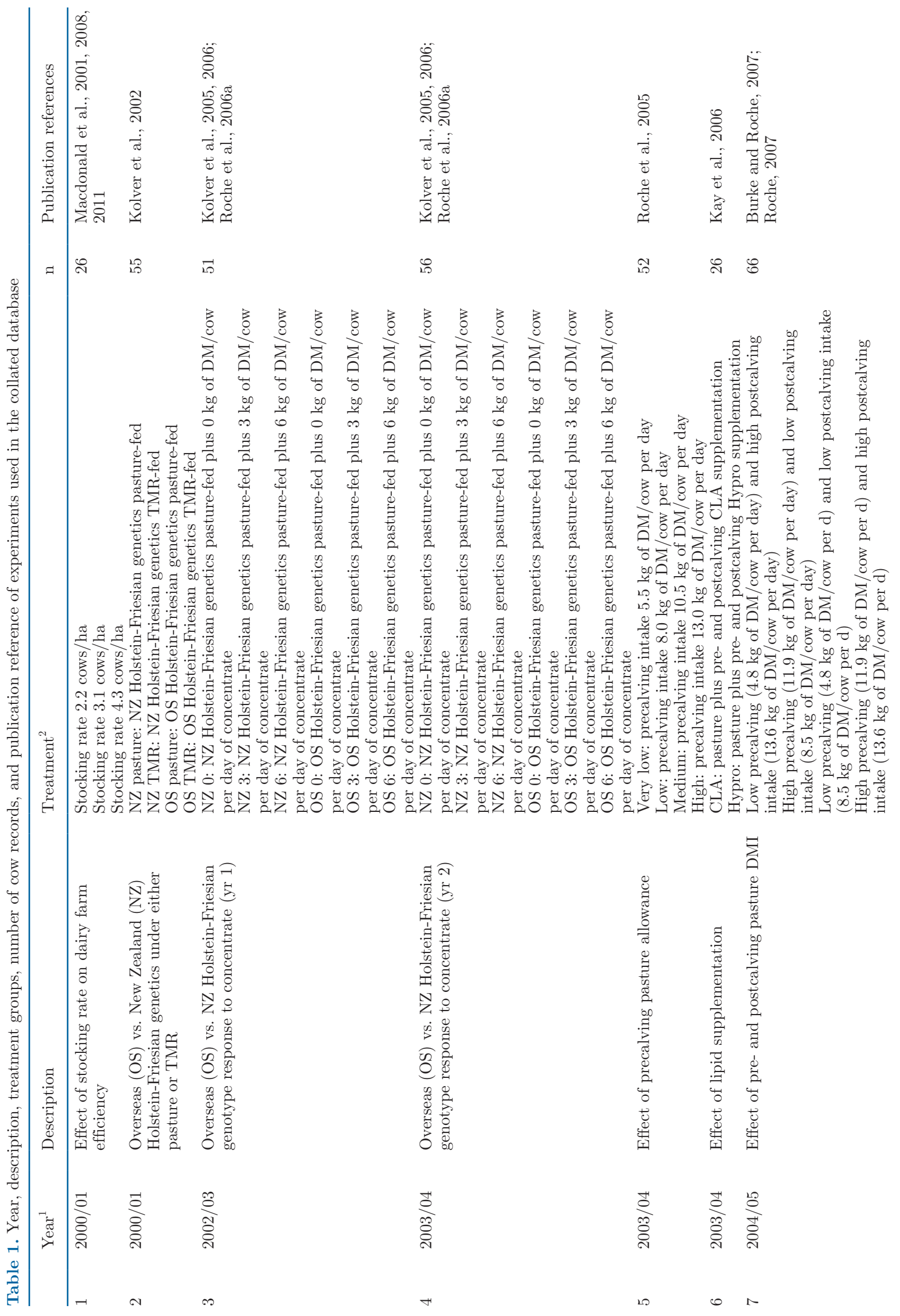


Spaans et al.: TEMPORAL PROFILES IN GRAZING DAIRY COWS

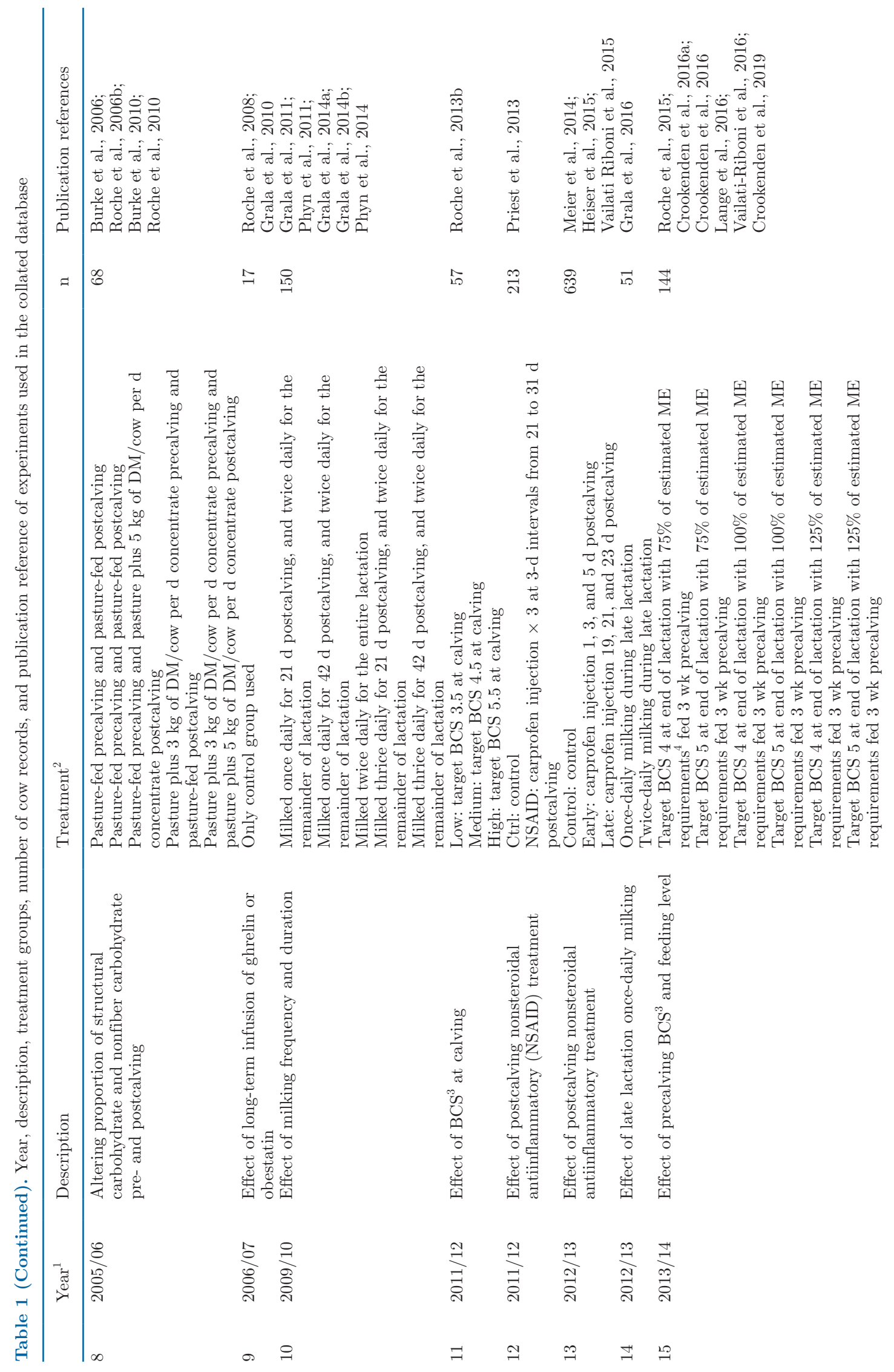




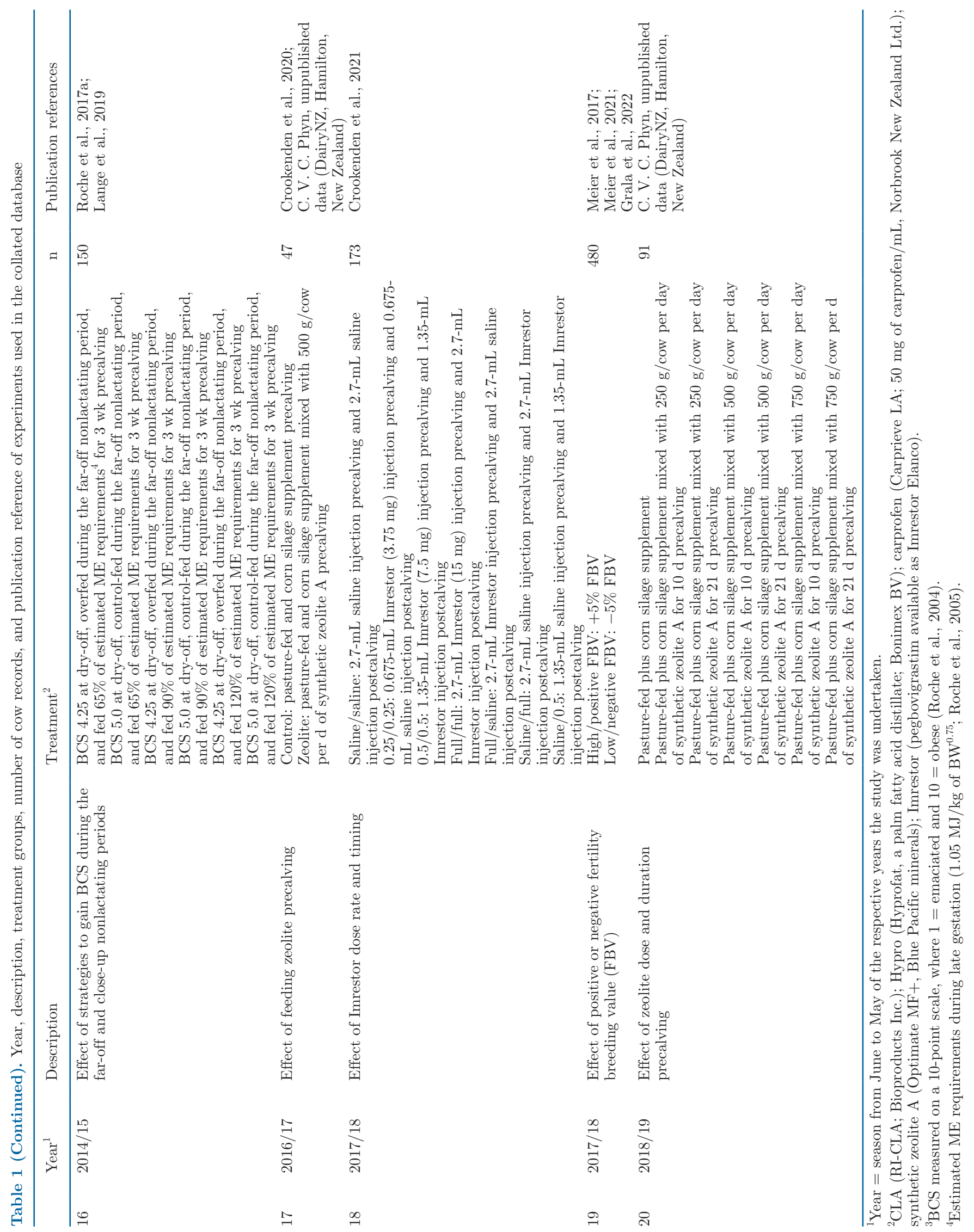


scale, where 1 is emaciated and 10 is obese (Roche et al., 2004). Scores can be converted to the 5 -point scale using the regression equation: 5 -point $=1.5+0.32 \times$ 10-point (Roche et al., 2004).

Unless otherwise stated, cows in all experiments were milked twice daily following calving and grazed predominantly ryegrass and white clover pasture, with a seasonal calving pattern. Cows were offered a generous pasture allowance and were managed to achieve a target BCS of 5.0 at calving, unless manipulated as part of the treatment design, in line with the pasture management decision rules described by Macdonald et al. (2010). Detailed descriptions of pasture and herd management, and pasture measurements are reported in the respective publications for each experiment (Table 1); briefly, cows were offered $>35 \mathrm{~kg}$ of DM/cow per day to ground level ( $\sim 20 \mathrm{~kg}$ of DM pasture available for consumption above grazing residual), had access to a fresh allocation of pasture at least once daily, and were rotationally grazed as one herd with grazing intervals ensuring they only returned to the same area when a minimum of 2 leaves had appeared on the majority (66\%) of perennial ryegrass tillers (Roche et al., 2017b). Generally, treatment groups were grazed in the same paddock separated by an electric fence to manage the herd pasture allocation and, therefore, had the same pregrazing pasture mass. Postgrazing residuals of $>1,800 \mathrm{~kg}$ of DM/ ha were targeted during spring and autumn and $>2,200$ $\mathrm{kg}$ of DM/ha during summer (Macdonald et al., 2010).

Body weight and BCS were generally determined either weekly or fortnightly at the a.m. milking or at $0900 \mathrm{~h}$ during the nonlactating period. Blood sampling and laboratory analyses were performed according to the methods outlined in the respective publications and presented in summary in Supplementary Material Appendix I (Spaans et al., 2021).

\section{Database Subset}

Each of the measurements collated in the database was formatted as a day relative to calving, where the calving date was $\mathrm{d} 0$. Calving date was defined as the day the calf was collected during daily calf retrieval (typically mid morning). The period between $28 \mathrm{~d}$ precalving and $35 \mathrm{~d}$ postcalving was chosen to select a subset of data to focus on the transition period. Because timing of blood sampling relative to calving date varied among the experiments, the days were grouped to the nearest week pre- or postcalving $\pm 3 \mathrm{~d}$. The exceptions were the groupings: $\mathrm{d}-30(30 \mathrm{~d}$ precalving $\pm 5 \mathrm{~d}), \mathrm{d}$ -3 (4 to 2 d precalving, d 0 ( $1 \mathrm{~d}$ precalving and day of calving), d 1.5 ( 1 and $2 \mathrm{~d}$ postcalving), and d 3.5 (3 and $4 \mathrm{~d}$ postcalving). Multiple observations for a cow were averaged to give the best estimate for each time point. Grouped time points were then clustered to give a precalving period of $\mathrm{d}-35$ to -2 (i.e., grouped time points $\mathrm{d}-30$ to -3 were clustered), a periparturient period of $\mathrm{d}-1$ to 2 (i.e., grouped time points of $\mathrm{d} 0$ and 1.5 were clustered), and a postcalving period of $\mathrm{d}$ 4 to 38 (i.e., grouped time points of d 3.5 to 35 were clustered).

\section{Data Analyses}

All data were analyzed using SAS Studio 3.8 (SAS release 9.04; SAS Institute Inc.). The mean, median, and standard deviation (SD) were calculated for each variable at each of the grouped time points (PROC MEANS). A repeated-measures mixed model (PROC MIXED) for effect of grouped day was fitted; fixed effects of parity, breed, and calving season day (CSD; number of days from the June 1 to actual calving date) were included as blocking factors or covariates; and treatment within experiment was included as a random effect. A compound symmetry covariance structure was included for all variables. A second mixed model included clustered period (precalving, periparturient, and postcalving) instead of grouped day as well as the same blocking factors and covariates. Data were $\log _{10}$ transformed to achieve homogeneity of variance for the following variables: urea, creatine kinase (CK), BHB, nonesterified fatty acids (NEFA), insulin, GH, IGF-1, aspartate aminotransferase (AST), glutamate dehydrogenase (GDH), cholesterol, $\gamma$-glutamyl transpeptidase (GGT), liver triacylglycerides (TAG), IL1及, IL-6, haptoglobin $(\mathbf{H p})$, reactive oxygen/nitrogen species (ROS), total antioxidant capacity (TAC), PMN, macrophage cells, and vaginal discharge score (0-5 scale; McDougall et al., 2020).

Parity was grouped as follows: group $1=$ parity 1 animals; group $2.5=$ parity 2 and 3 animals; group 5 $=$ parity 4 to 6 animals, inclusive; and group $7=$ parity $7+$ animals. Breed was grouped as $\mathrm{HF} \geq 12 / 16$ ths, $\mathrm{J} \geq 12 / 16$ ths, and $\mathrm{HF} \times \mathrm{J}<12 / 16$ ths $\mathrm{HF}$ or $\mathrm{J}$. The least squares means (LSM), maximum standard error of the difference (SED), mean, and upper SD for each variable at each grouped time point were plotted $(\mathrm{R}$ studio v4.0.1; https://www.r-project.org/). Maximum SED was the largest SED for any of the pairwise comparisons for LSM of different time points. For variables requiring $\log _{10}$ transformation, $P$-values presented are based on analysis of the transformed data, whereas LSM and SED are based on raw data.

To calculate prevalence of common transition cow disorders, established cut points from the literature were used as follows: (1) hyperketonemia (blood BHB): precalving $\geq 0.8 \mathrm{mmol} / \mathrm{L}$ (Chapinal et al., 2011; Ospina et al., 2013), moderate postcalving $\geq 1.2 \mathrm{mmol} / \mathrm{L}$ (LeB- 
lanc et al., 2005; Ospina et al., 2010b; Chapinal et al., 2012 ), and severe postcalving $\geq 3.0 \mathrm{mmol} / \mathrm{L}$ (Oetzel, 2004); (2) hyperlipidemia (blood NEFA): precalving $\geq 0.5 \mathrm{mmol} / \mathrm{L}$ and postcalving $\geq 1.0 \mathrm{mmol} / \mathrm{L}$ (LeBlanc et al., 2005; Chapinal et al., 2011; Bogado Pascottini and LeBlanc, 2020); (3) hepatic lipidosis (liver TAG): mild $1-5 \%$ wet weight, moderate $5-10 \%$ wet weight, and severe $>10 \%$ wet weight (Bobe et al., 2004); (4) hypocalcemia (blood total Ca): clinical pre- and postcalving $<1.4 \mathrm{mmol} / \mathrm{L}$ (DeGaris and Lean, 2008), subclinical pre- and postcalving $<2.0 \mathrm{mmol} / \mathrm{L}$ (Reinhardt et al., 2011) and $\leq 2.15 \mathrm{mmol} / \mathrm{L}$ (Neves et al., 2018; McArt and Neves, 2020), respectively; (5) hypomagnesemia (blood total $\mathrm{Mg}$ ): clinical pre- and postcalving $\leq 0.5 \mathrm{mmol} / \mathrm{L}$, subclinical pre- and postcalving $\leq 0.8$ $\mathrm{mmol} / \mathrm{L}$ (Goff, 2008); and (6) hypermagnesemia: preand postcalving $>1.1 \mathrm{mmol} / \mathrm{L}$ (Goff, 2008). Prevalence was expressed as the percentage of cows in each cut point group out of all the cows with data for the same time period.

\section{RESULTS}

The mean, SD, median, minimum and maximum values, number of observations, and LSM at each grouped time point are presented in Tables 2, 3, 4, 5, 6, and 7 for energy metabolism, liver function, protein metabolism, mineral status, inflammatory markers, and uterine and animal health variables, respectively. Temporal profiles of the mean, upper SD, LSM, and maximum SED for each variable are also presented in Figures 1 to 6 . The comparison between precalving, periparturient, and postcalving periods including the LSM and maximum SED are presented in Table 8. Overall, time significantly affected all variables, both by day $(P<0.001)$ and period $(P<0.05)$. Parity and breed also affect the concentration of many of these analytes (data not presented), but the shape of the profiles is not different.

\section{Indicators of Energy Metabolism, BCS, and BW}

Changes in the circulating concentrations of BHB, NEFA, glucose, insulin, GH, IGF-1, and leptin were used to monitor energy status and metabolism, with $\mathrm{BCS}$ and $\mathrm{BW}$ reflecting changes in body composition and energy reserves. Beta-hydroxybutyrate concentration gradually increased from a minimum LSM of 0.65 $\mathrm{mmol} / \mathrm{L}$ at $\mathrm{d}-30$ to $0.75 \mathrm{mmol} / \mathrm{L}$ at $\mathrm{d}-3(P<0.01)$, and then increased sharply around calving to a peak of $0.96 \mathrm{mmol} / \mathrm{L}$ by d $7(P<0.001$; Figure $1 \mathrm{~A})$. On average, postcalving concentrations of BHB were greater than precalving and periparturient concentrations $(P<$ 0.001; Table 8). During the period of $\mathrm{d} 7$ to 35 , the SD of BHB was noticeably increased, reflecting a greater maximal range of BHB concentrations for individual cows. The median was less than the mean indicating a skewed distribution of the data (Table 2) including a few very high values. The prevalence of precalving hyperketonemia $(\geq 0.80 \mathrm{mmol} / \mathrm{L})$ increased from $5 \%$ at $\mathrm{d}$ -30 to $17 \%$ at $d-14$, with a further increase to $25 \%$ at $\mathrm{d}-7$. Postcalving, the prevalence of moderate hyperketonemia ( $\geq 1.2 \mathrm{mmol} / \mathrm{L})$ ranged from $2 \%$ at $\mathrm{d} 0$ and d 1.5 to a maximum of $16 \%$ at d 7 , remaining around that level for the remainder of the observational period. Severe hyperketonemia prevalence $(\geq 3.0 \mathrm{mmol} / \mathrm{L})$ only reached a maximum of $2 \%$ at $\mathrm{d} 28$ and 35 .

Concentrations of NEFA (Figure 1B) increased from $0.30 \mathrm{mmol} / \mathrm{L}$ at $\mathrm{d}-30$ to $0.50 \mathrm{mmol} / \mathrm{L}$ at $\mathrm{d}-3(P<$ $0.001)$, with a rapid increase following calving to peak at a LSM concentration of $0.86 \mathrm{mmol} / \mathrm{L}$ at $\mathrm{d} 7(P<$ 0.001; Table 2). Nonesterified fatty acid concentration gradually declined thereafter but remained greater, on average, during the postcalving period than precalving $(P<0.001$; Table 8). Prevalence of precalving hyperlipidemia ( $\geq 0.5 \mathrm{mmol} / \mathrm{L})$ gradually increased from $23 \%$ at $\mathrm{d}-30$ to $55 \%$ at $\mathrm{d}-3$. Postcalving prevalence of hyperlipidemia $(\geq 1.0 \mathrm{mmol} / \mathrm{L})$ increased at each time point from $17 \%$ at $\mathrm{d} 0$ to a peak of $43 \%$ at $\mathrm{d} 7$, declining again gradually thereafter to $19 \%$ at d 35 .

Concentrations of glucose (Figure 1C) and insulin (Figure 1D) followed generally similar patterns. However, glucose concentrations remained stable at approximately $3.7 \mathrm{mmol} / \mathrm{L}$ leading up to calving with no differences between time points from $\mathrm{d}-30$ to $-3(P>$ $0.42)$; insulin concentrations, in comparison, decreased $(P<0.05)$ from 9.8 to $8.4 \mu \mathrm{U} / \mathrm{mL}$ between $\mathrm{d}-30$ and -21 , and remained stable to $\mathrm{d}-3$. Both glucose and insulin were markedly elevated around calving, increasing to $4.4 \mathrm{mmol} / \mathrm{L}$ and $10.9 \mu \mathrm{U} / \mathrm{mL}$, respectively, between $\mathrm{d}-3$ and $0(P<0.001)$. Thereafter, concentrations declined $(P<0.001)$ rapidly to reach $3.4 \mathrm{mmol} / \mathrm{L}$ for glucose and $5.9 \mu \mathrm{U} / \mathrm{mL}$ for insulin by $\mathrm{d} 7$. Both glucose and insulin subsequently remained relatively stable (Figure $1 \mathrm{C}$ and $\mathrm{D}$ ), but lower during the postcalving period than the precalving period $(P<0.001$; Table 8$)$. Median insulin concentrations were consistently lower than the means throughout the observational period, indicating a right skewed distribution of data (Table 2).

Concentrations of GH were stable during the precalving period (Figure 1E), with a mean of $4.1 \mathrm{ng} / \mathrm{mL}$ (Table 8). However, GH concentration spiked between $\mathrm{d}-3$ and $\mathrm{d} 0(P<0.001)$ to reach $30.9 \mathrm{ng} / \mathrm{mL}$, albeit with a large variation around this d 0 mean. Growth hormone rapidly decreased thereafter to $13.5 \mathrm{ng} / \mathrm{mL}$ at d $1.5(P<0.001)$. Concentrations then remained stable between d 3.5 and $35(P>0.79)$; however, there was more variation around the means at each grouped time point (Table 2) and the mean GH concentration dur- 
Spaans et al.: TEMPORAL PROFILES IN GRAZING DAIRY COWS

2676

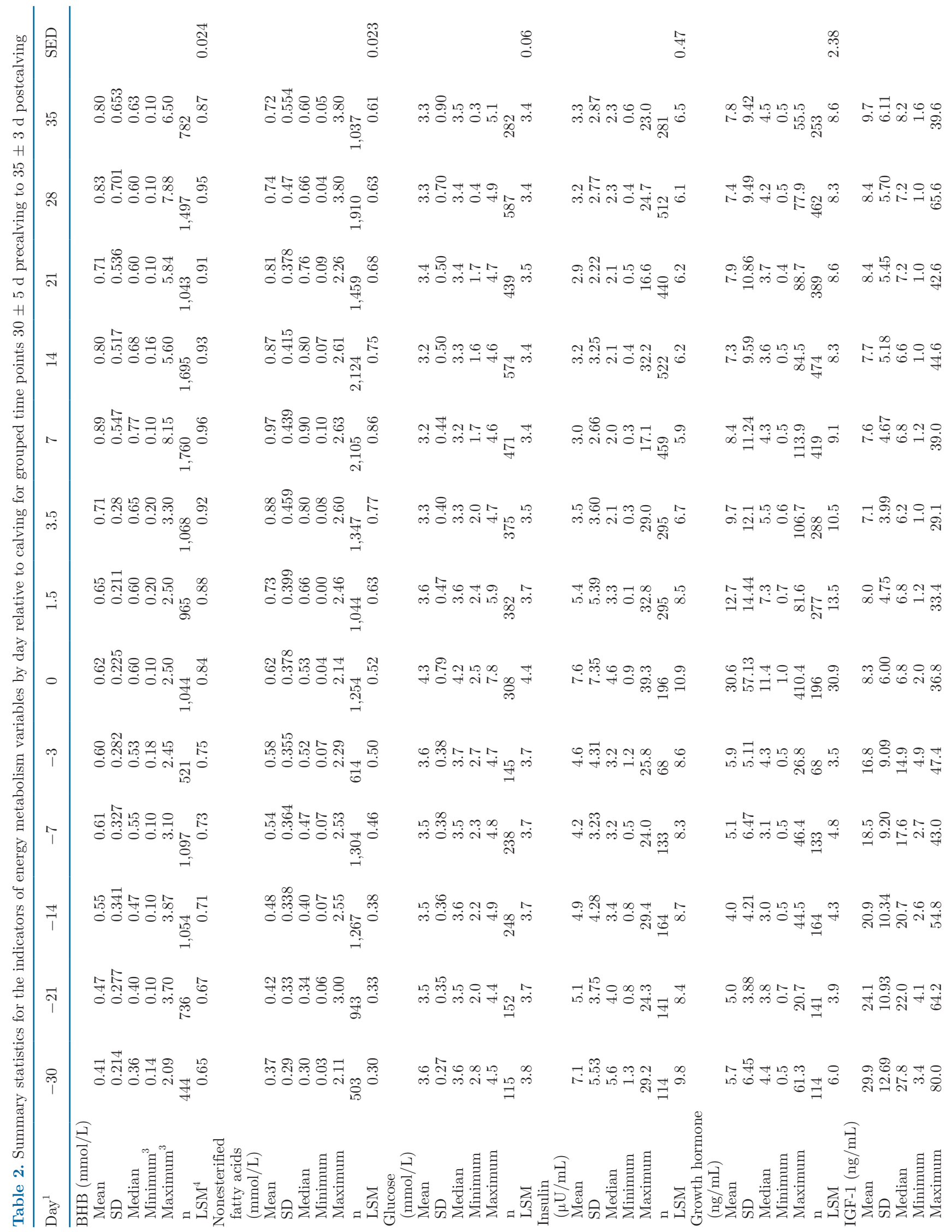


Spaans et al.: TEMPORAL PROFILES IN GRAZING DAIRY COWS

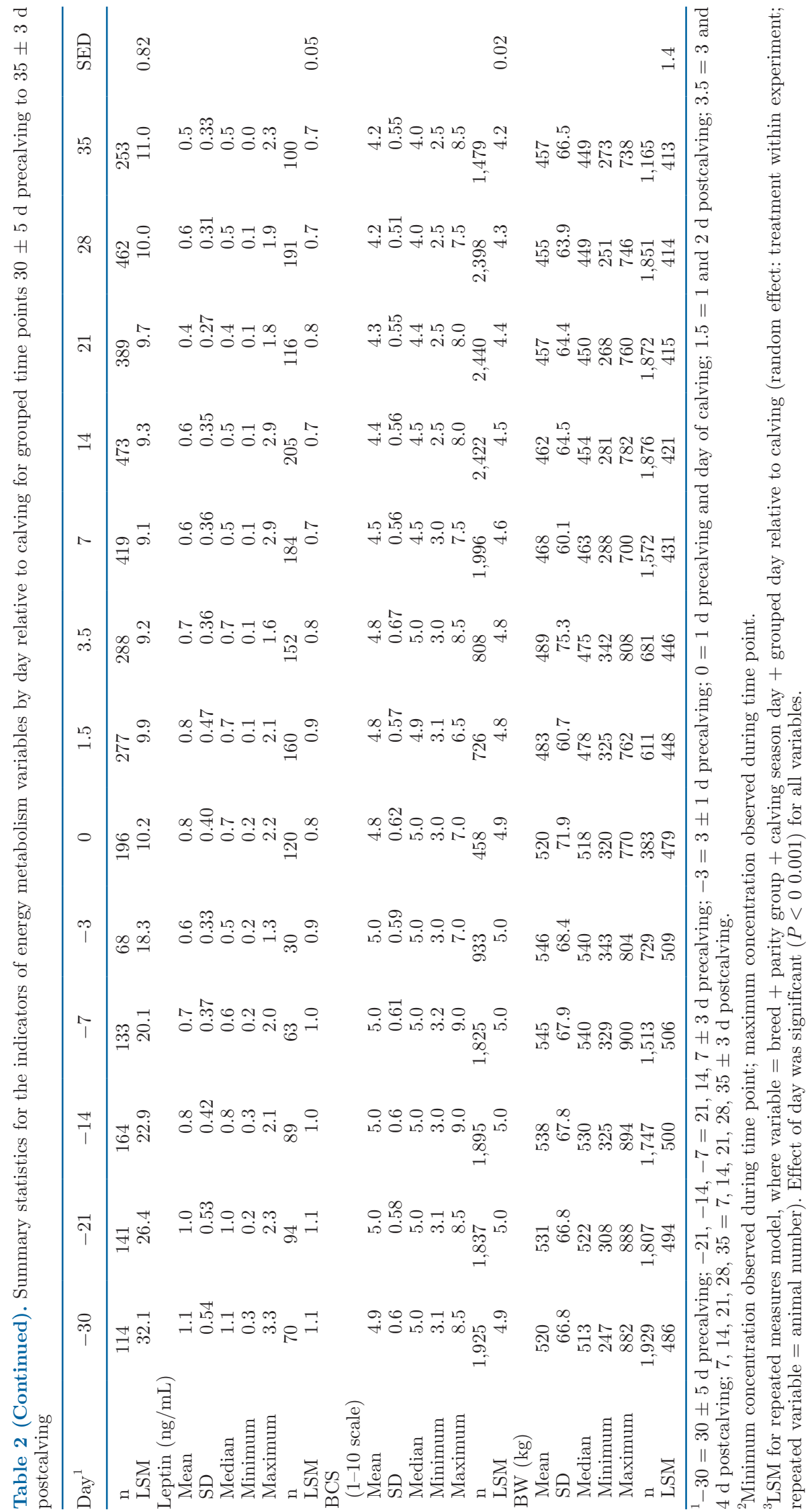


Spaans et al.: TEMPORAL PROFILES IN GRAZING DAIRY COWS

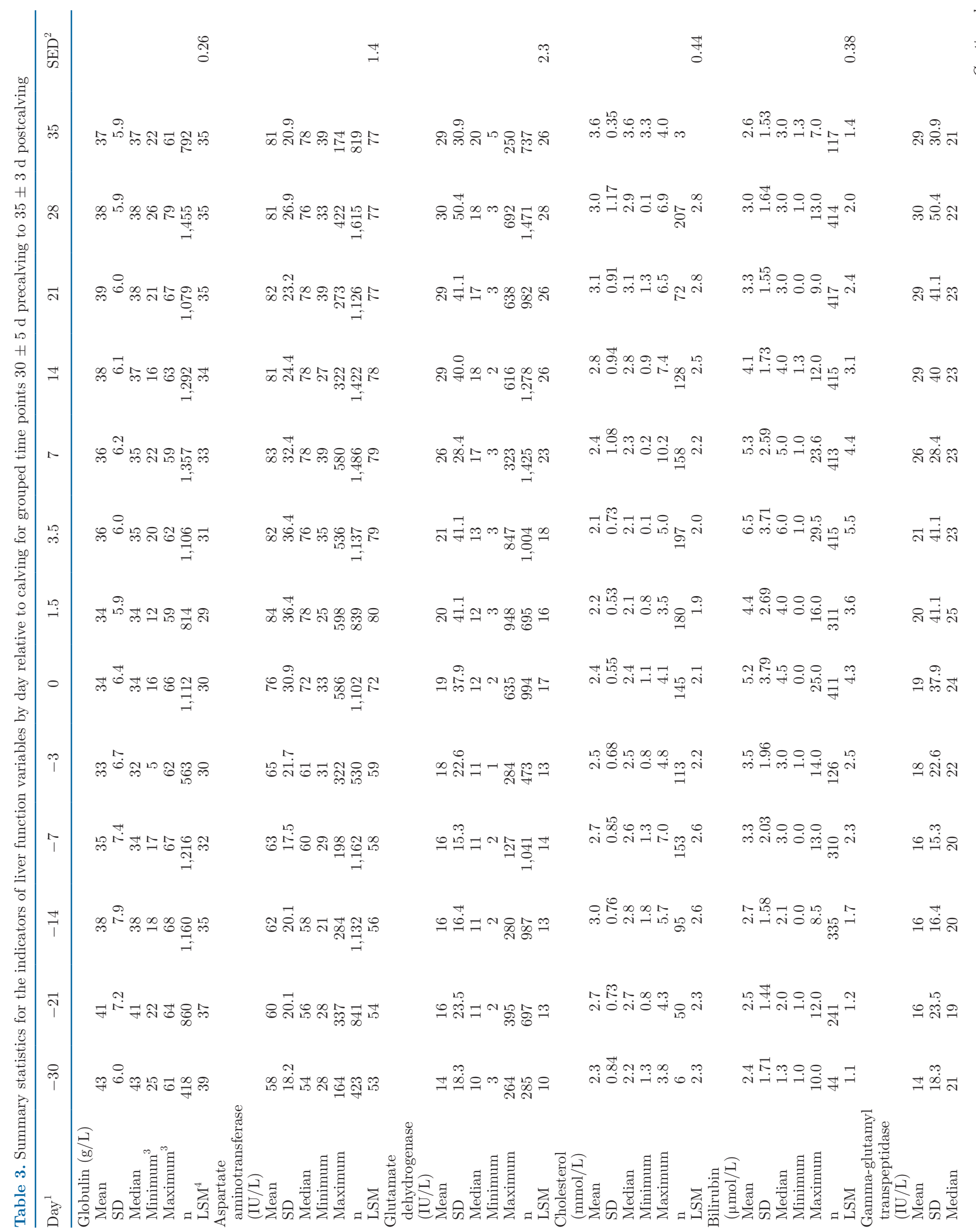




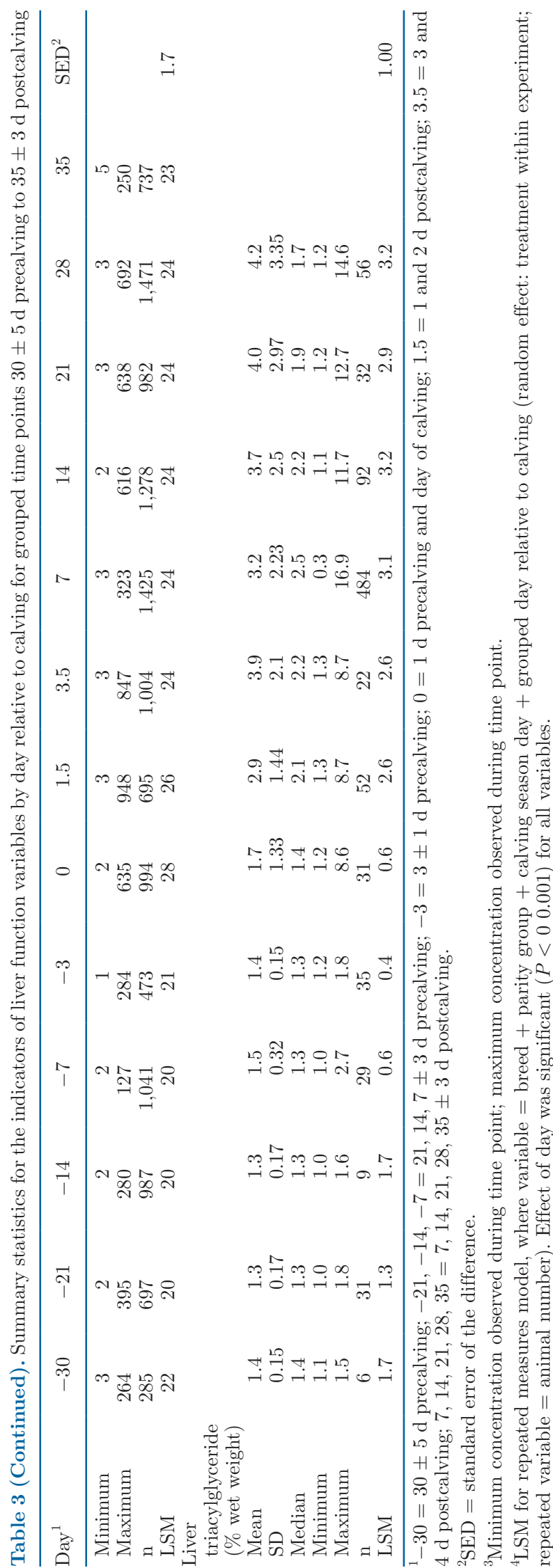

ing the postcalving period $(10.0 \mathrm{ng} / \mathrm{mL})$ was greater than precalving $(P<0.001$; Table 8$)$. The distribution of GH data was right skewed, indicated by median concentrations being consistently lower than the means throughout the observational period (Table 2).

Concentrations of IGF-1 decreased $(P<0.001)$ gradually from a peak concentration of $32.1 \mathrm{ng} / \mathrm{mL}$ at $\mathrm{d}$ -30 to $18.3 \mathrm{ng} / \mathrm{mL}$ at $\mathrm{d}-3$, with a rapid decrease at $\mathrm{d}$ 0 to $10.2 \mathrm{ng} / \mathrm{mL}(P<0.001 ;$ Figure $1 \mathrm{~F})$. Overall, IGF-1 concentrations remained lower through the postcalving than precalving period $(P<0.001$; Table 8$)$. At most time points, median IGF-1 concentrations were lower than means, reflecting a right skewed distribution of data (Table 2).

As with the profile of IGF-1, leptin concentrations were greatest at $\mathrm{d}-30$, decreasing gradually from 1.1 to $0.9 \mathrm{ng} / \mathrm{mL}$ at $\mathrm{d}-3(P<0.001$; Figure $1 \mathrm{G})$. Leptin concentrations were lower during the periparturient $(P$ $<0.001$ ) than precalving period, averaging $0.9 \mathrm{ng} / \mathrm{mL}$, and then decreased $(P<0.001)$ further to stabilize at about $0.8 \mathrm{ng} / \mathrm{mL}$ during the postcalving period (Table 8).

The LSM profile of BCS (Figure 1H) remained steady at about 4.9 BCS units precalving; however, there was large variation around the means (Table 2). The BCS decreased after calving from 5.0 BCS units at d -3 to 4.2 units at d $35(P<0.001$; Table 8$)$. In comparison, BW (Figure 1I) increased $(P<0.001)$ leading up to calving, from a LSM of $486 \mathrm{~kg}$ at d -30 to $509 \mathrm{~kg}$ at $\mathrm{d}-3$, before decreasing rapidly immediately after calving to $448 \mathrm{~kg}$ at $\mathrm{d} 1.5(P<0.001)$. Body weight gradually declined thereafter to reach $415 \mathrm{~kg}$ at d $21(P$ $<0.001$; Table 2). For both BCS and BW, precalving values were greater than the periparturient period $(P$ $<0.001)$, with the postcalving period lower than both previous periods $(P<0.001$; Table 8$)$.

\section{Indicators of Liver Function}

Variations in the concentrations of globulin, AST, GDH, bilirubin, cholesterol, GGT, and liver TAG were examined as indicators of change in liver function. Plasma globulin concentration slowly decreased in the weeks preceding calving: from 39 to $30 \mathrm{~g} / \mathrm{L}$ between $\mathrm{d}$ -30 and $\mathrm{d}-3(P<0.001$; Figure $2 \mathrm{~A})$, and was lower during the periparturient period than either the pre- or postcalving periods $(P<0.001$; Table 8$)$. Concentrations of globulin increased by $\mathrm{d} 3.5$ postcalving and stabilized around $35 \mathrm{~g} / \mathrm{L}$ between $\mathrm{d} 21$ and d $35(P$ $>0.17$ ). In contrast, mean AST activities (Figure 2B) gradually increased from 53 to $59 \mathrm{IU} / \mathrm{L}$ between $\mathrm{d}-30$ and $-3(P<0.01)$, followed by a rapid increase in AST to $72-80 \mathrm{IU} / \mathrm{L}$ at $\mathrm{d} 0$ to $1.5(P<0.001)$. A greater variation among cows was indicated by larger $\mathrm{SD}$ val- 
Spaans et al.: TEMPORAL PROFILES IN GRAZING DAIRY COWS

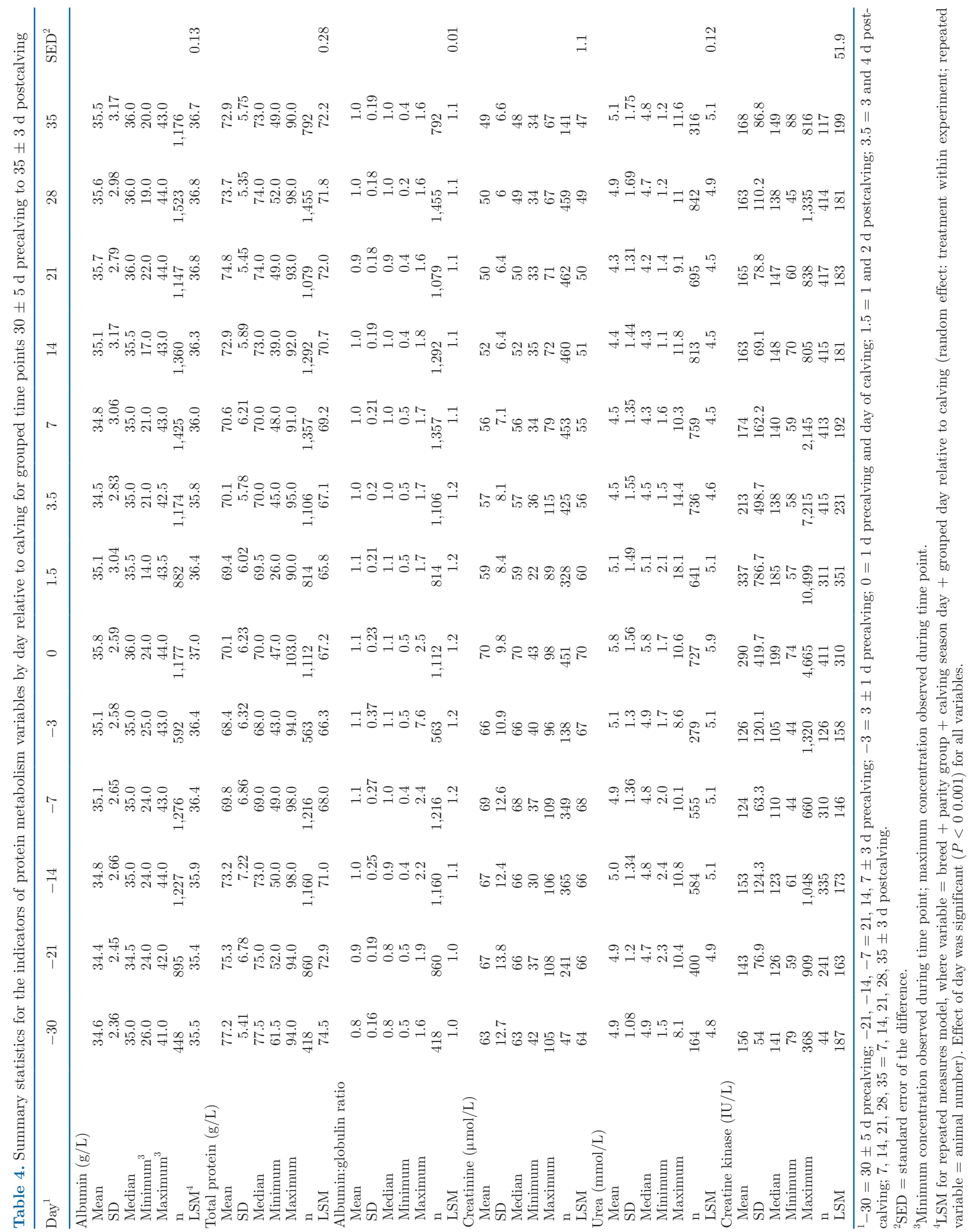


ues during the first week following calving (Table 3). Generally, postcalving AST activity remained greater than precalving $(P<0.001$; Table 8$)$ and stabilized around 77 to $79 \mathrm{IU} / \mathrm{L}$, with no differences between $\mathrm{d}$ 3.5 and $35(P>0.26$; Table 3$)$.

Mean GDH activity (Figure $2 \mathrm{C}$ ) was stable precalving, ranging between 10 and $14 \mathrm{IU} / \mathrm{L}$ during $\mathrm{d}-30$ and $-3(P>0.87)$. Glutamate dehydrogenase activity increased following calving and reached $23 \mathrm{IU} / \mathrm{L}$ by d $7(P<0.01$ relative to $\mathrm{d} 1.5$ or 3.5$)$. Thereafter, GDH activity remained greater during the postcalving period than the periparturient and precalving periods $(P<$ 0.001; Table 8) and stabilized around $26 \mathrm{IU} / \mathrm{L}$ with no significant differences between $\mathrm{d} 14$ and $35(P>$ $0.93)$. However, greater variation in GDH was evident (i.e., larger SD values) during the periparturient and postcalving periods (Table 3 ). In addition, median GDH activity was lower than means from d 7 to 35 , indicating a right-skewed distribution of data at these time points (Table 3).

Cholesterol decreased steadily from $2.6 \mathrm{mmol} / \mathrm{L}$ at d -14 and -7 to $1.9 \mathrm{mmol} / \mathrm{L}$ at d $1.5(P<0.001$; Figure $2 \mathrm{D}$ ), before increasing over the first few weeks of lactation to reach $2.8 \mathrm{mmol} / \mathrm{L}$ by d 21. Bilirubin increased from 1.1 to $2.5 \mu \mathrm{mol} / \mathrm{L}$ between $\mathrm{d}-30$ and $-3(P<$ $0.05)$, which was followed by a rapid increase at calving to a peak mean concentration of $5.5 \mu \mathrm{mol} / \mathrm{L}$ at d $3.5(P$ $<0.001$ relative to $\mathrm{d}-3$; Figure $2 \mathrm{E}$ ). Thereafter, bilirubin concentrations decreased to $1.4 \mu \mathrm{mol} / \mathrm{L}$ at d 35 $(P<0.001)$; however, the postcalving LSM remained higher than the precalving LSM $(P<0.001$; Table 8$)$. An increased degree of variation in bilirubin was indicated by larger SD values during the periparturient period and the first week postcalving (Table 3).

Mean activities of GGT (Figure 2F) were stable, averaging $20 \mathrm{IU} / \mathrm{L}$, during the 4 wk leading up to calving $(P>0.99)$; there was a rapid increase in activity to 28 $\mathrm{IU} / \mathrm{L}$ on the day of calving $(P<0.01$ relative to each time point precalving). During the first week postcalving, GGT activity decreased $(P<0.001)$ to $24 \mathrm{IU} / \mathrm{L}$ by $\mathrm{d} 3.5$ and remained at this level to d $35(P>0.93)$. Accordingly, postcalving GGT activity was greater, on average, than precalving activity $(P<0.001$; Table 8$)$. Large variation was also apparent around the means for each time point, especially in the periparturient and postcalving periods (Table 3 ).

During the precalving period, liver TAG content (Figure $2 \mathrm{G}$ ) was stable $(P>0.75)$, averaging $1.6 \%$ wet weight, with little variation at each time point; however, both the LSM, mean, and SD of TAG content increased at d 1.5 and remained greater throughout the postcalving period, averaging $3.3 \%$ wet weight $(P<$ 0.001; Table 3). Precalving prevalence of mild hepatic lipidosis (1-5\% wet weight) ranged from $100 \%$ at $\mathrm{d}-30$ to $75 \%$ at $\mathrm{d}-3$, but there was no moderate or severe hepatic lipidosis prevalent. Following calving, mild hepatic lipidosis prevalence gradually decreased from $93 \%$ at $\mathrm{d} 0$ to $57 \%$ at $\mathrm{d} 35$, and moderate hepatic lipidosis (5-10\% wet weight) prevalence increased from $2 \%$ at $\mathrm{d}$ 0 to $13 \%$ at d 28. Severe hepatic lipidosis ( $>10 \%$ wet weight) was only prevalent from d 14, ranging from $3 \%$ at this time to $5 \%$ at d 28. Overall, most cows with TAG data had some degree of increased hepatic lipidosis postcalving. Furthermore, the median of TAG content was lower than the mean from d 3.5 to 35 , indicating a skew in the distribution of TAG data at each of these time points (Table 3 ).

\section{Indicators of Protein Metabolism}

Variations in the mean concentrations of albumin, total protein, albumin:globulin ratio (AGR), creatinine, urea, and CK were examined to provide an indication of protein metabolism. Mean concentrations of albumin (Figure $3 \mathrm{~A}$ ) varied within a $2 \mathrm{~g} / \mathrm{L}$ range during the observation period (Table 4). However, there was large variation around the means at each time point. Albumin concentrations were lowest at 35.5 and $35.4 \mathrm{~g} / \mathrm{L}$ at $\mathrm{d}-30$ and -21 , respectively, and increased $(P<0.001)$ thereafter to peak at $37.0 \mathrm{~g} / \mathrm{L}$ on the day of calving. Following calving, albumin immediately decreased $(P$ $<0.001$ ) to a nadir of $35.8 \mathrm{~g} / \mathrm{L}$ at d 3.5 , before gradually increasing again to 36.8 at d 21 (Table 4). There was no difference between pre- and postcalving average plasma albumin concentrations, although albumin was greater during the periparturient period $(P<0.001$; Table 8).

Total protein decreased from a maximum of 74.5 to $66.3 \mathrm{~g} / \mathrm{L}$ between $\mathrm{d}-30$ and $-3(P<0.001$; Figure $3 \mathrm{~B})$ and remained lower during the periparturient period $(P$ $<0.001)$. Circulating concentrations of total protein increased from $67.1 \mathrm{~g} / \mathrm{L}$ at d 3.5 to $72.0 \mathrm{~g} / \mathrm{L}$ at d 21 $(P<0.001)$ and remained stable thereafter $(P>0.52)$. The AGR increased from 1.0 to 1.2 between $\mathrm{d}-30$ and $-7(P<0.001$; Figure $3 \mathrm{C})$ and remained at this ratio during the periparturient period until d 3.5 when the AGR decreased $(P<0.001)$ to a plateau at 1.1 between d 7 and 35 (Table 4).

Creatinine concentrations were greatest and had a higher SD during the precalving period (Figure 3D; Table 4). Creatinine gradually increased from 64 $\mu \mathrm{mol} / \mathrm{L}$ at $\mathrm{d}-30$ to $68 \mu \mathrm{mol} / \mathrm{L}$ at $\mathrm{d}-7(P<0.01)$. Immediately following calving, creatinine decreased from a maximum of $70 \mu \mathrm{mol} / \mathrm{L}$ at d 0 to $60 \mu \mathrm{mol} / \mathrm{L}$ by d $1.5(P<0.001)$, with a steady decline thereafter to $47 \mu \mathrm{mol} / \mathrm{L}$ at d 35 . Urea concentrations remained stable throughout the precalving period $(P>0.19$; Figure 3E; Table 4), averaging $5.1 \mathrm{mmol} / \mathrm{L}$. Urea con- 
Spaans et al.: TEMPORAL PROFILES IN GRAZING DAIRY COWS

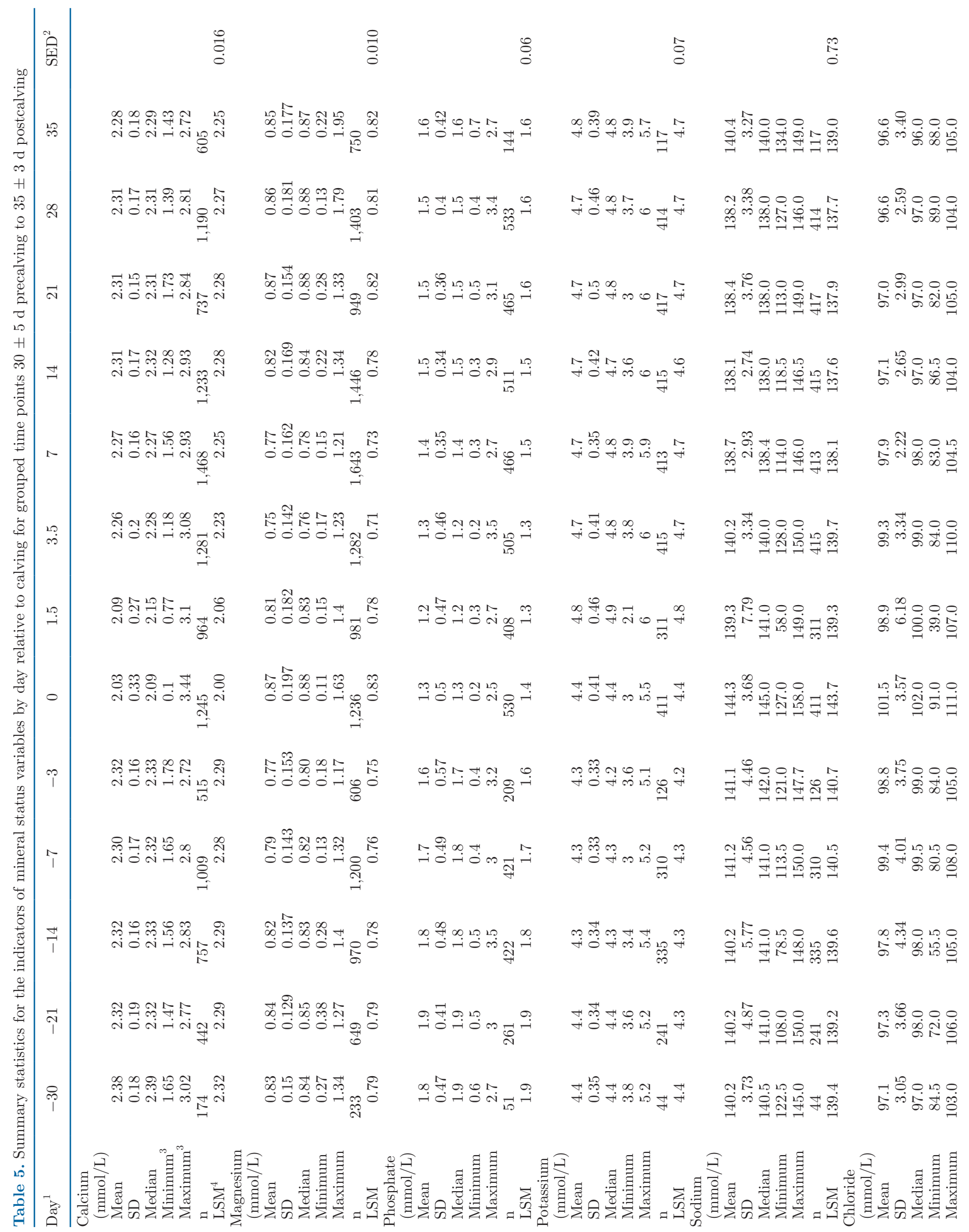




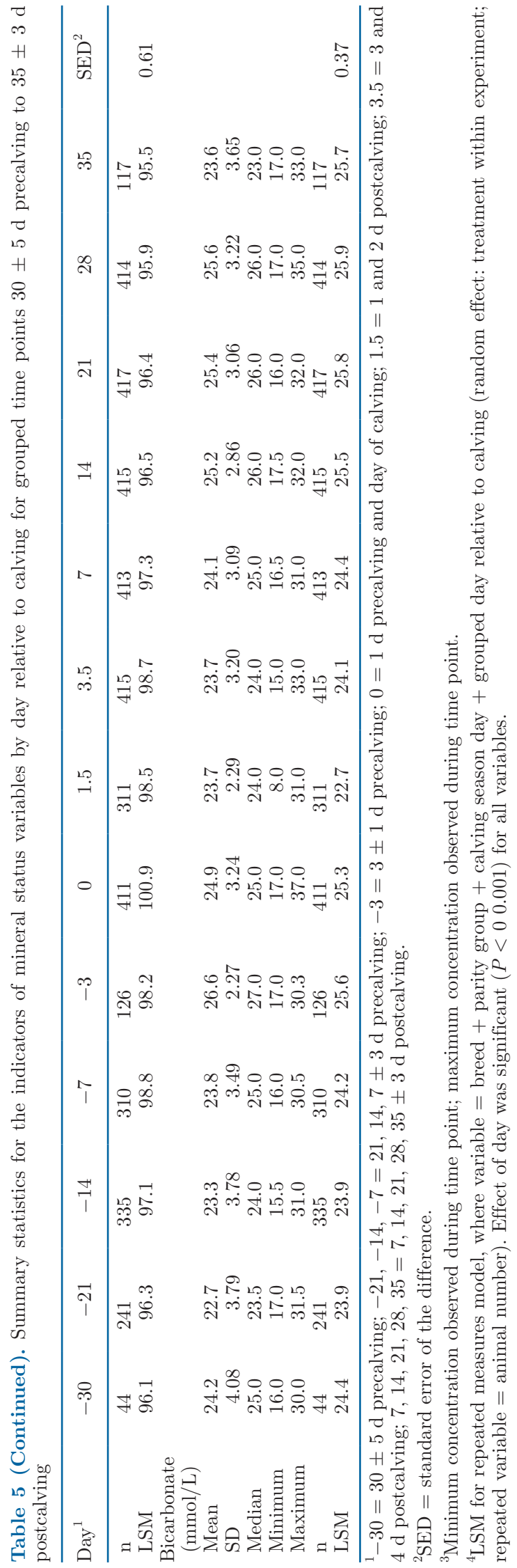

centration increased to $5.9 \mathrm{mmol} / \mathrm{L}$ at calving $(P<$ 0.001 relative to all time points), but decreased $(P$ $<0.001)$ back to $5.1 \mathrm{mmol} / \mathrm{L}$ at $\mathrm{d} 1.5$ and further decreased $(P<0.001)$ to $4.6 \mathrm{mmol} / \mathrm{L}$ at d 3.5 (Figure $3 \mathrm{E})$. Concentrations of urea remained constant at approximately $4.5 \mathrm{mmol} / \mathrm{L}$ between $\mathrm{d} 3.5$ and $21(P>$ $0.81)$ and increased $(P<0.001)$ thereafter to reach $5.1 \mathrm{mmol} / \mathrm{L}$ at $\mathrm{d} 35$. Urea concentrations were lower postcalving than both the precalving and periparturient periods $(P<0.001)$, with the periparturient greater than the precalving period $(P<0.001$; Table $8)$. During the pre- and postcalving periods, mean CK activity (Figure 3F) remained relatively stable between 146 and $231 \mathrm{IU} / \mathrm{L}$ and did not differ $(P=$ 0.11 ; Table 8). However, CK activities doubled to 351 $\mathrm{IU} / \mathrm{L}$ at $\mathrm{d} 1.5(P<0.05$ relative to each time point in the pre- and postcalving periods) and were highly variable through the periparturient period (Table 4). Median CK activity was consistently lower than the mean activity throughout the observational period, and by a considerable amount at some time points, thereby suggesting a large skew in the distribution of CK data (Table 4).

\section{Indicators of Mineral Balance}

Minerals that were measured as indicators of transition cow health were $\mathrm{Ca}, \mathrm{Mg}$, phosphate $\left(\mathrm{PO}_{4}\right), \mathrm{K}, \mathrm{Na}$, $\mathrm{Cl}$, and bicarbonate. Mean Ca concentration during the precalving period was approximately $2.3 \mathrm{mmol} / \mathrm{L}$, with a rapid decrease in circulating concentration from 2.29 $\mathrm{mmol} / \mathrm{L}$ to a nadir of $2.00 \mathrm{mmol} / \mathrm{L}$ between $\mathrm{d}-3$ and d $0(P<0.001)$. Following calving, mean Ca concentration increased, remaining at approximately $2.2 \mathrm{mmol} / \mathrm{L}$ from d 3.5 to 35 (Table 5). Prevalence of subclinical hypocalcemia using a cut point of $<2.0 \mathrm{mmol} / \mathrm{L}$ was $35 \%$ and $28 \%$ on $\mathrm{d} 0$ and 1.5 , respectively. Using a greater cut point of $\leq 2.15 \mathrm{mmol} / \mathrm{L}$, it increased to $60 \%$ and $50 \%$ on $\mathrm{d} 0$ and 1.5 , respectively. The prevalence of clinical hypocalcemia $(\leq 1.4 \mathrm{mmol} / \mathrm{L})$ was $6 \%$ and $3 \%$ on $\mathrm{d} 0$ and 1.5 , respectively.

The profile of mean $\mathrm{Mg}$ concentration (Figure 4B) was inverse to $\mathrm{Ca}$, with an increase in concentration from 0.75 to $0.83 \mathrm{mmol} / \mathrm{L}$ between $\mathrm{d}-3$ and $0(P<$ 0.001; Table 5). There were no differences between pre- and postcalving $\mathrm{Mg}$ concentration, with a LSM of $0.81 \mathrm{mmol} / \mathrm{L}$ for both periods $(P=0.75$; Table $8)$. The prevalence of subclinical hypomagnesemia $(\leq 0.8 \mathrm{mmol} / \mathrm{L})$ and clinical hypomagnesemia $(\leq 0.5$ $\mathrm{mmol} / \mathrm{L}$ ) consistently ranged from $30 \%$ to $46 \%$ and $2 \%$ to $6 \%$, respectively, throughout the observational period. Subclinical hypomagnesemia peaked during the periparturient period at $64 \%$ at $d$ 3.5. Prevalence of hypermagnesemia $(\geq 1.1 \mathrm{mmol} / \mathrm{L})$ on d 0 was $9 \%$, which 
Spaans et al.: TEMPORAL PROFILES IN GRAZING DAIRY COWS

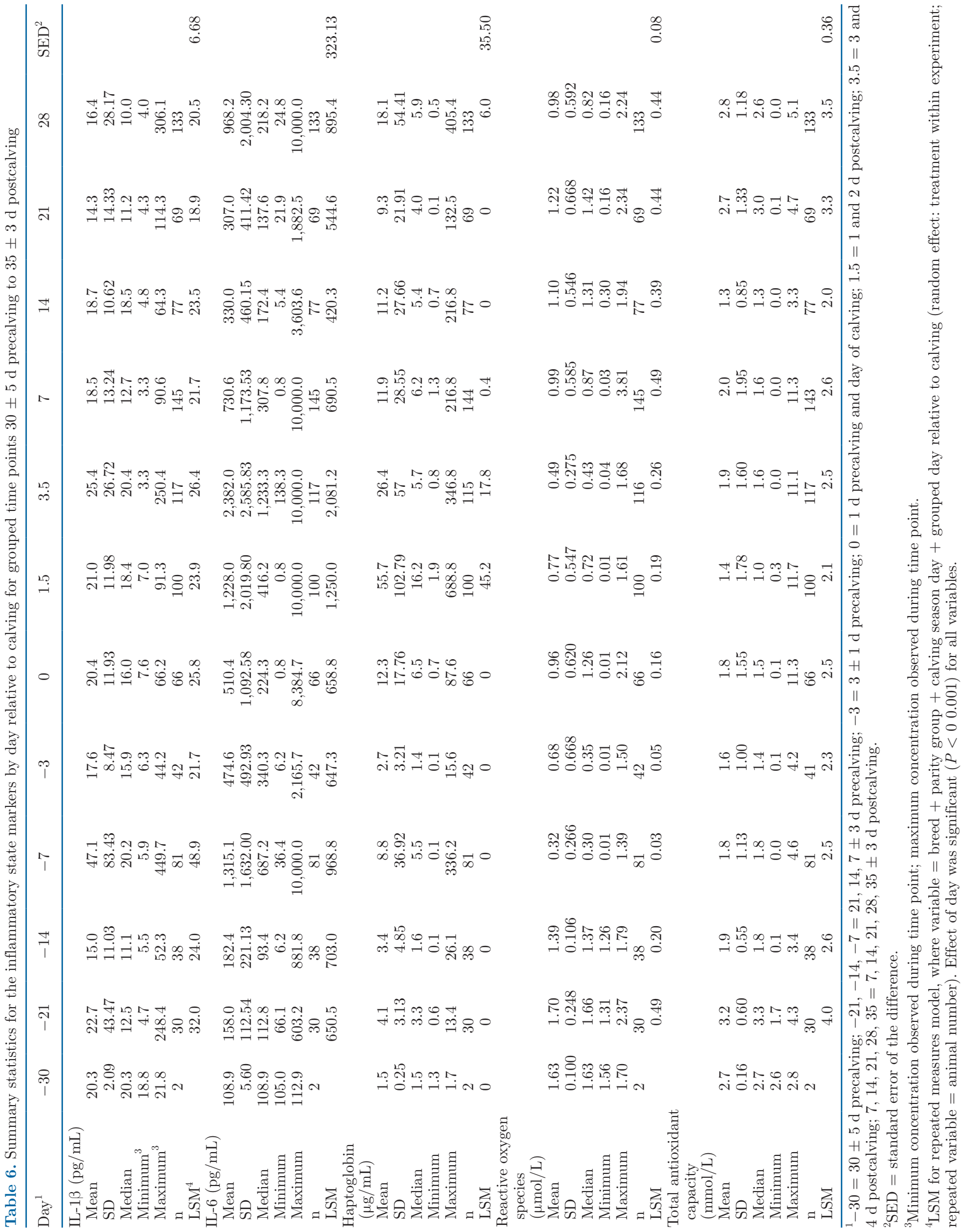


Table 7. Summary statistics for indicators of uterine health markers by day relative to calving for grouped time points $3 \pm 1 \mathrm{~d}$ postcalving to $35 \pm 3$ d postcalving

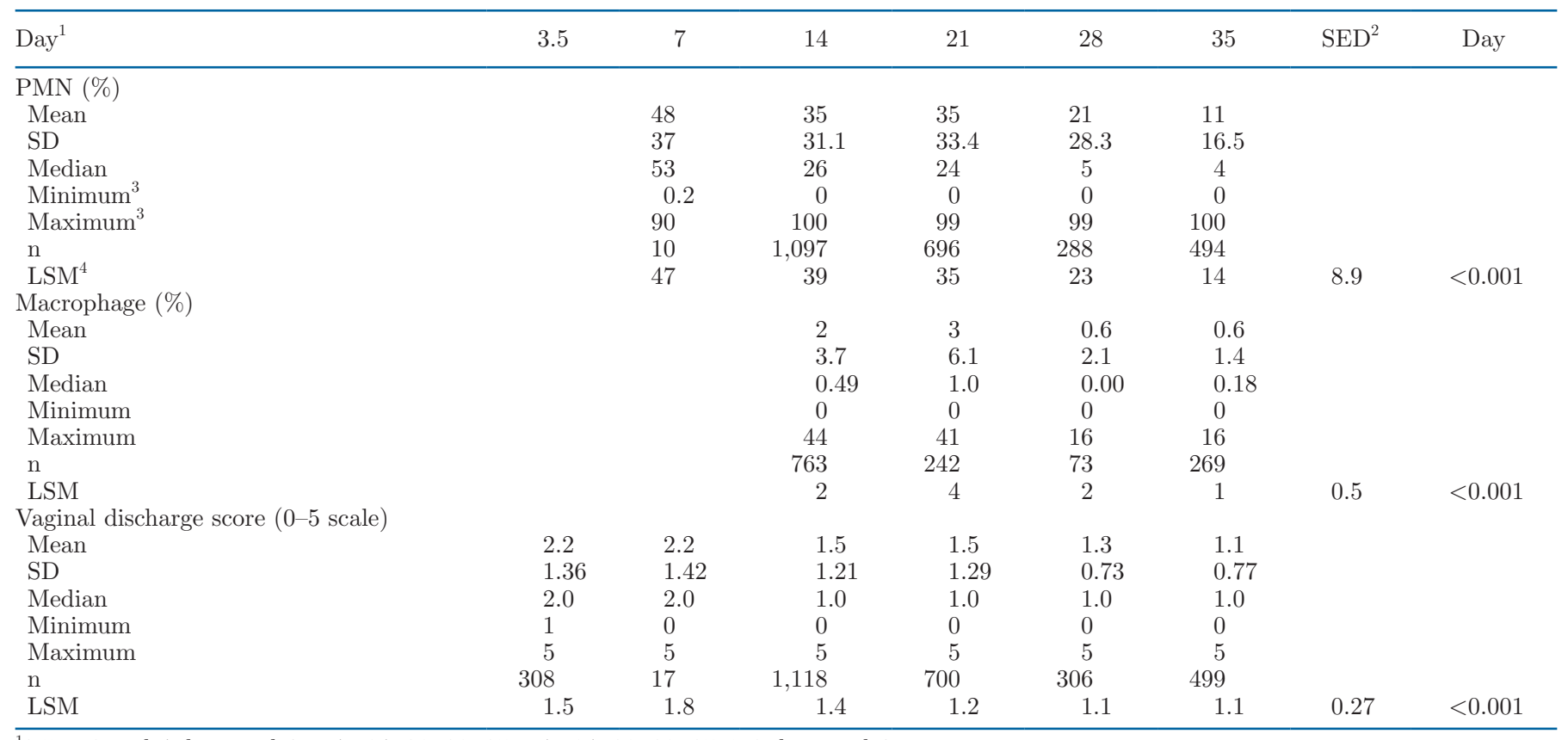

${ }^{1} 3.5=3$ and $4 \mathrm{~d}$ postcalving; $7,14,21,28,35=7,14,21,28,35 \pm 3 \mathrm{~d}$ postcalving.

${ }^{2} \mathrm{SED}=$ standard error of the difference.

${ }^{3}$ Minimum concentration observed during time point; maximum concentration observed during time point.

${ }^{4} \mathrm{LSM}$ for repeated measures model, where variable = breed + parity group + calving season day + grouped day relative to calving (random effect: treatment within experiment; repeated variable = animal number).

decreased immediately to $5 \%$ at d 1.5 and further to $1 \%$ at $\mathrm{d} 7$.

Mean $\mathrm{PO}_{4}$ concentrations decreased through the precalving period, from $1.9 \mathrm{mmol} / \mathrm{L}$ at $\mathrm{d}-30$ to 1.6 $\mathrm{mmol} / \mathrm{L}$ at $\mathrm{d}-3(P<0.001$; Figure $4 \mathrm{C})$. Concentrations of $\mathrm{PO}_{4}$ rapidly decreased on the day of calving to $1.4 \mathrm{mmol} / \mathrm{L}$, followed by a further decrease to a nadir of $1.3 \mathrm{mmol} / \mathrm{L}$ at d 1.5 (Table 5 ). By d 7, concentrations of $\mathrm{PO}_{4}$ had increased to $1.5 \mathrm{mmol} / \mathrm{L}$, but they remained lower postcalving than precalving $(P<$ 0.001; Table 8).

Concentrations of $\mathrm{K}$ remained relatively stable around $4.3 \mathrm{mmol} / \mathrm{L}$ through the precalving period (Figure 4D; $P>0.90$ relative to all precalving time points), before increasing on the day of calving to $4.8 \mathrm{mmol} / \mathrm{L}$ at d $1.5(P<0.001$; Table 5$)$. Mean $\mathrm{K}$ concentrations remained around $4.7 \mathrm{mmol} / \mathrm{L}$ thereafter, which resulted in greater concentrations postcalving compared with precalving $(P<0.001$; Table 8$)$.

Mean concentrations of $\mathrm{Na}$ (Figure 4E) also remained stable around $139 \mathrm{mmol} / \mathrm{L}$ precalving, but increased $(P$ $<0.001$; Table 5) on the day of calving to $144 \mathrm{mmol} / \mathrm{L}$. By d 1.5, Na concentrations had decreased and, on average, remained lower than the precalving and periparturient periods at a concentration of approximately $137 \mathrm{mmol} / \mathrm{L}$ from d 7 to $28(P<0.001$; Table 5$)$.
The profile of mean $\mathrm{Cl}$ concentration (Figure 4F) was similar to that of $\mathrm{Na}$, although there was a slight increase in $\mathrm{Cl}$ concentration through the precalving period $(P<0.001$; Table 5). Peak LSM Cl concentration of $101 \mathrm{mmol} / \mathrm{L}$ occurred on the day of calving, with an immediate decrease to $98.5 \mathrm{mmol} / \mathrm{L}$ at d 1.5, and a gradual decrease back to $96 \mathrm{mmol} / \mathrm{L}$ by d 14 (Table 5 ).

Overall, bicarbonate concentrations during the postcalving period were greater than those during the periparturient period, which, in turn, were greater than the precalving period $(P<0.05$; Table 8$)$. There was a sharp decrease at calving from $25.3 \mathrm{mmol} / \mathrm{L}$ on $\mathrm{d} 0$ to $22.7 \mathrm{mmol} / \mathrm{L}$ on d $1.5(P<0.001$; Table 6$)$.

\section{Indicators of Inflammation}

Changes in concentrations of IL-1 $\beta$, IL-6, Hp, ROS, and TAC were examined as indicators of inflammation. Mean IL-1 $\beta$ concentration (Figure 5A) peaked on $\mathrm{d}-7$ at $48.9 \mathrm{pg} / \mathrm{mL}(P<0.01)$, but with a large $\mathrm{SD}$, before decreasing to a relatively stable postcalving concentration of approximately 20 to $25 \mathrm{pg} / \mathrm{mL}$ by d $0(P>0.86$ relative to all postcalving time points; Table 6). Consequently, the precalving LSM tended to be greater than the LSM for the periparturient $(P=$ $0.06)$ and was greater than the postcalving $(P<0.001)$ 
Table 8. Least squares means of repeated measures model ${ }^{1}$ for each of the indicators of energy metabolism, liver function, protein metabolism, mineral status, acute phase, and uterine and animal health for the precalving (Pre; d -35 to -2 ), periparturient (Peri; d -1 to 2 ), and postcalving (Post; d 4 to 38 ) periods

\begin{tabular}{|c|c|c|c|c|c|}
\hline Item $^{2}$ & Pre & Peri & Post & $\mathrm{SED}^{3}$ & Period \\
\hline \multicolumn{6}{|l|}{ Energy metabolism } \\
\hline $\mathrm{BHB}(\mathrm{mmol} / \mathrm{L})$ & 0.60 & 0.75 & 0.84 & 0.012 & $<0.001$ \\
\hline NEFA (mmol/L) & 0.47 & 0.62 & 0.77 & 0.011 & $<0.001$ \\
\hline Glucose $(\mathrm{mmol} / \mathrm{L})$ & 3.66 & 3.99 & 3.41 & 0.025 & $<0.001$ \\
\hline Insulin $(\mu \mathrm{U} / \mathrm{mL})$ & 6.77 & 7.29 & 4.27 & 0.271 & $<0.001$ \\
\hline Growth hormone $(\mathrm{ng} / \mathrm{mL})$ & 4.12 & 18.98 & 10.02 & 1.210 & $<0.001$ \\
\hline IGF $(\mathrm{ng} / \mathrm{mL})$ & 23.7 & 9.4 & 8.8 & 0.45 & $<0.001$ \\
\hline Leptin (ng/mL) & 1.1 & 0.9 & 0.8 & 0.02 & $<0.001$ \\
\hline BCS $(1-10)$ & 4.9 & 4.7 & 4.4 & 0.02 & $<0.001$ \\
\hline $\mathrm{BW}(\mathrm{kg})$ & 503 & 466 & 427 & 0.86 & $<0.001$ \\
\hline \multicolumn{6}{|l|}{ Liver function } \\
\hline Globulin $(\mathrm{g} / \mathrm{L})$ & 37 & 32 & 37 & 0.1 & $<0.001$ \\
\hline $\operatorname{AST}(\mathrm{IU} / \mathrm{L})$ & 58 & 77 & 78 & 0.9 & $<0.001$ \\
\hline GDH (IU/L) & 18 & 22 & 30 & 1.0 & $<0.001$ \\
\hline Cholesterol (mmol/L) & 2.7 & 2.2 & 2.6 & 0.06 & $<0.001$ \\
\hline Bilirubin $(\mu \mathrm{mol} / \mathrm{L})$ & 2.9 & 5.1 & 4.3 & 0.14 & $<0.001$ \\
\hline GGT (IU/L) & 20 & 28 & 24 & 0.9 & $<0.001$ \\
\hline Liver TAG ( $\%$ of wet weight) & 1.6 & 2.6 & 3.3 & 0.23 & $<0.001$ \\
\hline \multicolumn{6}{|l|}{ Protein metabolism } \\
\hline $\operatorname{Albumin}(\mathrm{g} / \mathrm{L})$ & 35 & 36 & 35 & 0.1 & $<0.001$ \\
\hline Total protein $(\mathrm{g} / \mathrm{L})$ & 72 & 68 & 72 & 0.1 & $<0.001$ \\
\hline Albumin:globulin ratio & 1.0 & 1.2 & 1.0 & 0.01 & $<0.001$ \\
\hline Creatinine $(\mu \mathrm{mol} / \mathrm{L})$ & 66 & 65 & 51 & 0.4 & $<0.001$ \\
\hline Urea $(\mathrm{mmol} / \mathrm{L})$ & 5.1 & 5.5 & 4.7 & 0.05 & $<0.001$ \\
\hline Creatine kinase (IU/L) & 137 & 306 & 175 & 19 & $<0.001$ \\
\hline \multicolumn{6}{|l|}{ Mineral balance } \\
\hline Sodium $(\mathrm{mmol} / \mathrm{L})$ & 140.8 & 142.7 & 139.0 & 0.21 & $<0.001$ \\
\hline Potassium (mmol/L) & 4.3 & 4.6 & 4.7 & 0.02 & $<0.001$ \\
\hline Chloride $(\mathrm{mmol} / \mathrm{L})$ & 98.1 & 100.9 & 97.7 & 0.19 & $<0.001$ \\
\hline Bicarbonate (mmol/L) & 24.4 & 24.7 & 25.5 & 0.11 & $<0.001$ \\
\hline Phosphate $(\mathrm{mmol} / \mathrm{L})$ & 1.8 & 1.3 & 1.5 & 0.02 & $<0.001$ \\
\hline Calcium $(\mathrm{mmol} / \mathrm{L})$ & 2.32 & 2.06 & 2.28 & 0.007 & $<0.001$ \\
\hline Magnesium (mmol/L) & 0.81 & 0.84 & 0.81 & 0.005 & $<0.001$ \\
\hline \multicolumn{6}{|l|}{ Inflammation } \\
\hline $\mathrm{IL}-1 \beta(\mathrm{pg} / \mathrm{mL})$ & 35.0 & 24.3 & 19.0 & 4.68 & $<0.01$ \\
\hline IL-6 $(\mathrm{pg} / \mathrm{mL})$ & 602.2 & 956.2 & 784.4 & 120.57 & 0.32 \\
\hline Haptoglobin $(\mu \mathrm{g} / \mathrm{mL})$ & 0.0 & 31.9 & 10.5 & 4.68 & $<0.001$ \\
\hline $\operatorname{ROS}(\mu \mathrm{mol} / \mathrm{L})$ & 0.35 & 0.53 & 0.63 & 0.072 & $<0.001$ \\
\hline $\mathrm{TAC}(\mathrm{mmol} / \mathrm{L})$ & 2.9 & 2.6 & 3.1 & 0.16 & $<0.01$ \\
\hline \multicolumn{6}{|l|}{ Uterine health } \\
\hline PMN (\%) & & & 29 & $3.9^{4}$ & \\
\hline Macrophage (\%) & & & 2 & $0.8^{4}$ & \\
\hline Vaginal discharge score $(0-5)$ & & & 1.2 & $0.14^{4}$ & \\
\hline
\end{tabular}

${ }^{1}$ Least squares means for repeated measures model, where variable $=$ breed + parity group + calving season day + period (random effect: treatment within experiment; repeated variable $=$ animal number).

${ }^{2} \mathrm{NEFA}=$ nonesterified fatty acids; AST $=$ aspartate aminotransferase; GDH = glutamate dehydrogenase; GGT = gamma-glutamyl transpeptidase; TAG = triacylglyceride; $\mathrm{ROS}=$ reactive oxygen species; $\mathrm{TAC}=$ total antioxidant capacity; BCS (1-10 scale; Roche et al., 2004).

${ }^{3} \mathrm{SED}=$ standard error of the difference.

${ }^{4}$ SEM for variables with only postcalving measurements.

periods, which did not differ from each other $(P=0.48$; Table 8). Mean concentrations of IL-6 (Figure 5B) were greatest during the first $4 \mathrm{~d}$ after calving, trebling from $647.3 \mathrm{pg} / \mathrm{mL}$ at $\mathrm{d}-3$ to $2,081.2 \mathrm{pg} / \mathrm{mL}$ at $\mathrm{d} 3.5(P<$ 0.001 ), before declining again. A large SD and range of concentrations for IL-6 were also apparent during this time (Table 6). Overall, there was an increase in IL-6 concentration from the precalving to periparturi- ent period $(P<0.01)$; however, there was no difference between the pre- and postcalving concentrations or between periparturient and postcalving concentrations $(P>0.17$; Table 8).

Mean Hp concentration (Figure 5C) was lowest during the precalving period, with an increase in LSM, mean, and SD at calving, to a peak of $45.2 \mu \mathrm{g} / \mathrm{mL}$ at d $1.5(P<0.001$; Table 6$)$. Haptoglobin was lower 
during the postcalving period than the periparturient period $(P<0.001)$ but remained greater than precalving $(P=0.02$; Table 8$)$. The LSM concentration of ROS decreased through the precalving period from 0.49 $\mu \mathrm{mol} / \mathrm{L}$ at $\mathrm{d}-21$ to $0.03 \mu \mathrm{mol} / \mathrm{L}$ at $\mathrm{d}-3(P<0.001$; Figure 5D). By d 7, concentrations had increased back to $0.49 \mu \mathrm{mol} / \mathrm{L}$ and remained stable thereafter $(P>$ 0.60 relative to all postcalving time points; Table 6$)$.
Overall, postcalving ROS concentrations were greater than precalving concentrations $(P<0.001)$, with periparturient concentrations intermediary (Table 8).

For IL-1 $\beta$, IL-6, Hp, and ROS, median concentrations were lower than means at most of the time points, indicating a skewed distribution for each of these indicators of inflammation during most of the observational period (Table 6).
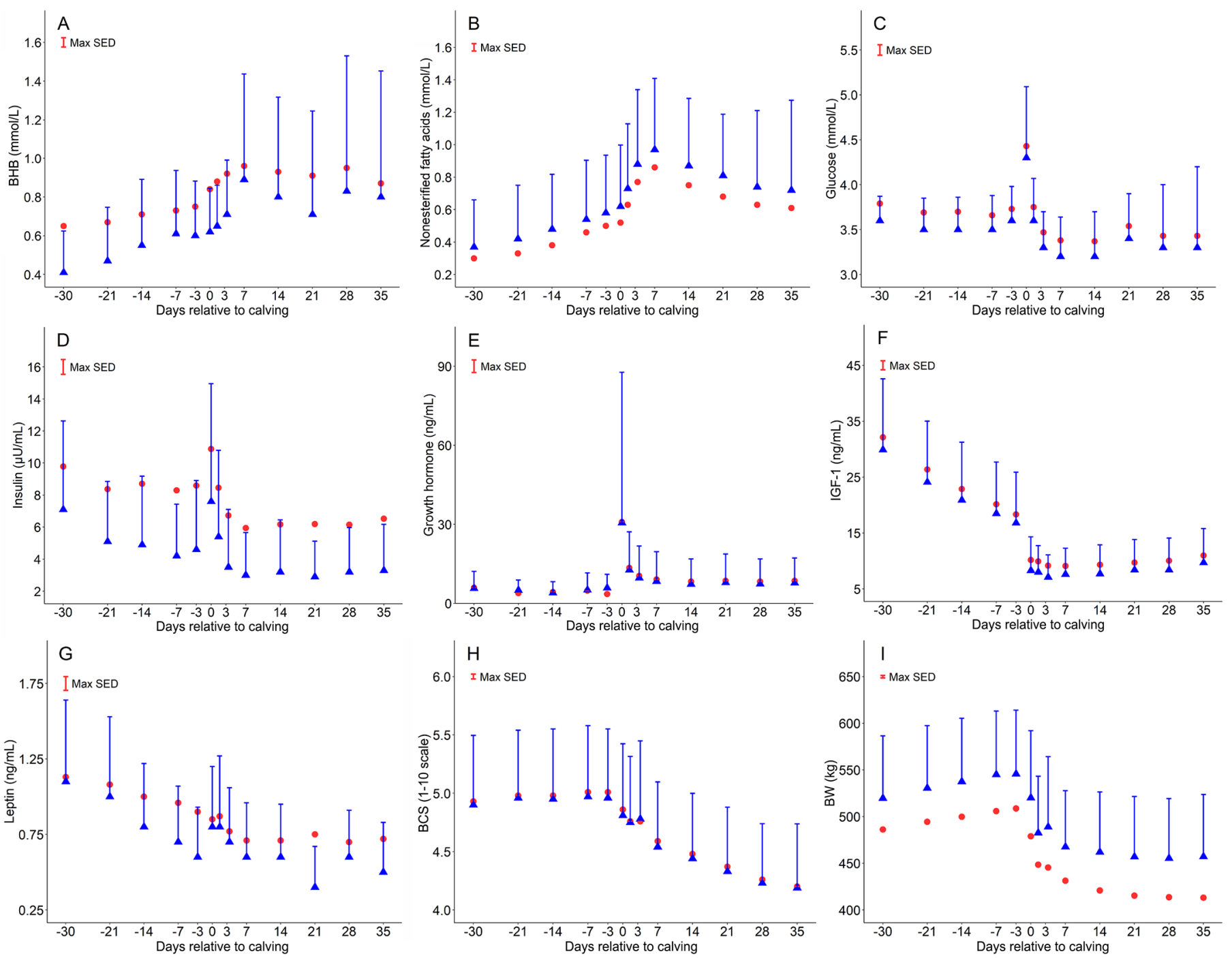

Figure 1. Mean (blue triangles) and upper SD, LSM (red circles), and maximum standard error of the difference (Max SED) for concentrations of energy indicator analytes. (A) $\beta$-Hydroxybutyrate $(\mathrm{mmol} / \mathrm{L}),(\mathrm{B})$ nonesterified fatty acids $(\mathrm{mmol} / \mathrm{L}),(\mathrm{C}) \mathrm{glucose}(\mathrm{mmol} / \mathrm{L}),(\mathrm{D})$ insulin $(\mu \mathrm{U} / \mathrm{mL})$, (E) growth hormone $(\mathrm{ng} / \mathrm{mL}),(\mathrm{F})$ IGF-1 $(\mathrm{ng} / \mathrm{mL}),(\mathrm{G})$ leptin $(\mathrm{ng} / \mathrm{mL})$, and animal health measures $(\mathrm{H})$ BCS $(1-10 \mathrm{scale})$ and $(\mathrm{I})$ $\mathrm{BW}(\mathrm{kg})$ for the population of grazing dairy cows in the collated database with selected grouped time points by days relative to calving (d 0 ). Least squares means for repeated measures model, where variable $=$ breed + parity group + calving season day + grouped day relative to calving (random effect: treatment within experiment; repeated variable $=$ animal number); breed: Holstein-Friesian $(\geq 12 / 16$ ths Holstein-Friesian genetics), Holstein-Friesian $\times$ Jersey crossbred, and Jersey ( $\geq 12 / 16$ ths Jersey genetics); parity: group $1=$ parity 1 animals, group $2.5=$ parity 2 and 3 animals, group $5=$ parity 4 to 6 animals, group $7=$ parity $7+$ animals; calving season day: number of days between June 1 and calving date in the year of calving. $\mathrm{d}-30=30 \mathrm{~d} \pm 5 \mathrm{~d}$ precalving; $\mathrm{d}-21,-14,-7=21,14,7 \mathrm{~d} \pm 3 \mathrm{~d}$ precalving; $\mathrm{d}-3=\mathrm{d} 3 \pm 1 \mathrm{~d}$ precalving; $\mathrm{d} 0$ $=\mathrm{d} 1$ precalving and day of calving; $\mathrm{d} 1.5=\mathrm{d} 1$ and 2 postcalving; $\mathrm{d} 3.5=\mathrm{d} 3$ and 4 postcalving; $\mathrm{d} 7,14,21,28,35=7,14,21,28$, and $35 \mathrm{~d}$ \pm 3 d postcalving. 
Mean TAC concentration was greatest at $4.0 \mathrm{mmol} / \mathrm{L}$ at $\mathrm{d}-21$, decreasing to a relatively stable concentration of around $2.5 \mathrm{mmol} / \mathrm{L}$ from $\mathrm{d}-14$ to $7(P>$ 0.88 relative to any time point between; Figure $5 \mathrm{E}$ ). Concentrations reached a nadir of $2.0 \mathrm{mmol} / \mathrm{L}$ at d 14 before increasing to $3.3 \mathrm{mmol} / \mathrm{L}$ at d $21(P<0.001$; Table 6). As a result, TAC concentrations during the periparturient period tended to be lower than the pre- calving period $(P=0.07)$, with no difference between the pre- and postcalving periods $(P>0.49$; Table 8$)$.

\section{Uterine Health}

Together, PMN \%, macrophage \%, and vaginal discharge score provide an indication of uterine health. From d 7 to 35, PMN \% (Figure 6A) decreased from a
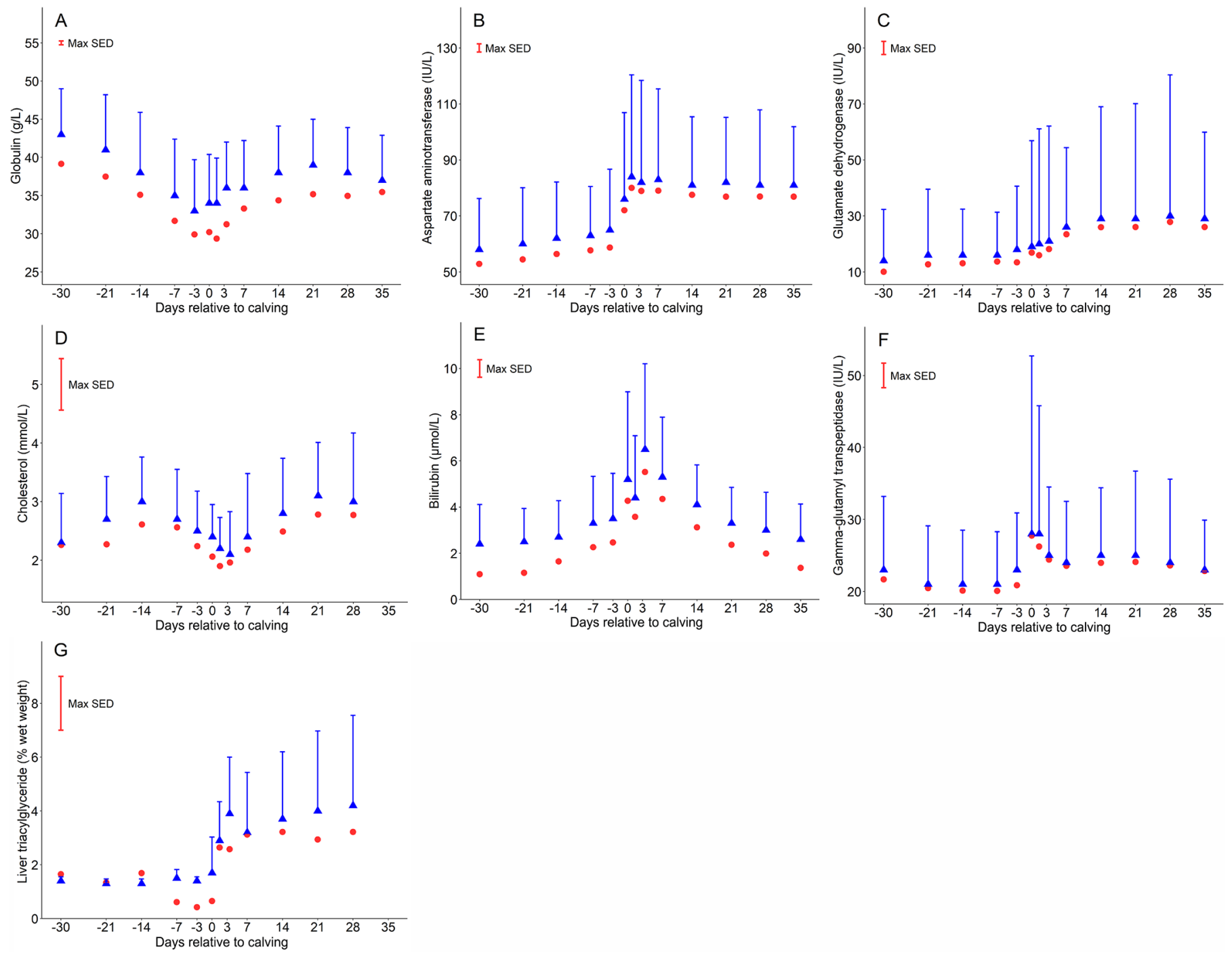

Figure 2. Mean (blue triangles) and upper SD, LSM (red circles), and maximum standard error of the difference (Max SED) for concentrations of liver function analytes. (A) Globulin (g/L), (D) cholesterol (mmol/L), (E) bilirubin (mmol/L), and (G) liver triacylglyceride (\% of wet weight) and activities of liver enzymes, (B) aspartate aminotransferase (IU/L), (C) glutamate dehydrogenase (IU/L), and (F) $\gamma$-glutamyl transpeptidase (IU/L) for the population of grazing dairy cows in the collated database with selected grouped time points by day relative to calving ( $\mathrm{d}$ 0). Least squares means for repeated measures model, where variable $=$ breed + parity group + calving season day + grouped day relative to calving (random effect: treatment within experiment; repeated variable $=$ animal number); breed: Holstein-Friesian $(>12 / 16$ ths Holstein-Friesian genetics), Holstein-Friesian $\times$ Jersey crossbred, and Jersey ( $\geq 12 / 16$ ths Jersey genetics); parity: group $1=$ parity 1 animals, group $2.5=$ parity 2 and 3 animals, group $5=$ parity 4 to 6 animals, and group $7=$ parity $7+$ animals; calving season day: number of days between June 1 and calving date in the year of calving. $\mathrm{d}-30=30 \mathrm{~d} \pm 5 \mathrm{~d}$ precalving; $\mathrm{d}-21,-14,-7=21,14,7 \mathrm{~d} \pm 3 \mathrm{~d}$ precalving; $\mathrm{d}-3$ $=\mathrm{d} 3 \pm 1 \mathrm{~d}$ precalving; $\mathrm{d} 0=\mathrm{d} 1$ precalving and day of calving; $\mathrm{d} 1.5=\mathrm{d} 1$ and 2 postcalving; $\mathrm{d} 3.5=\mathrm{d} 3$ and 4 postcalving; $\mathrm{d} 7,14,21,28$, $35=7,14,21,28,35 \mathrm{~d} \pm 3 \mathrm{~d}$ postcalving. 

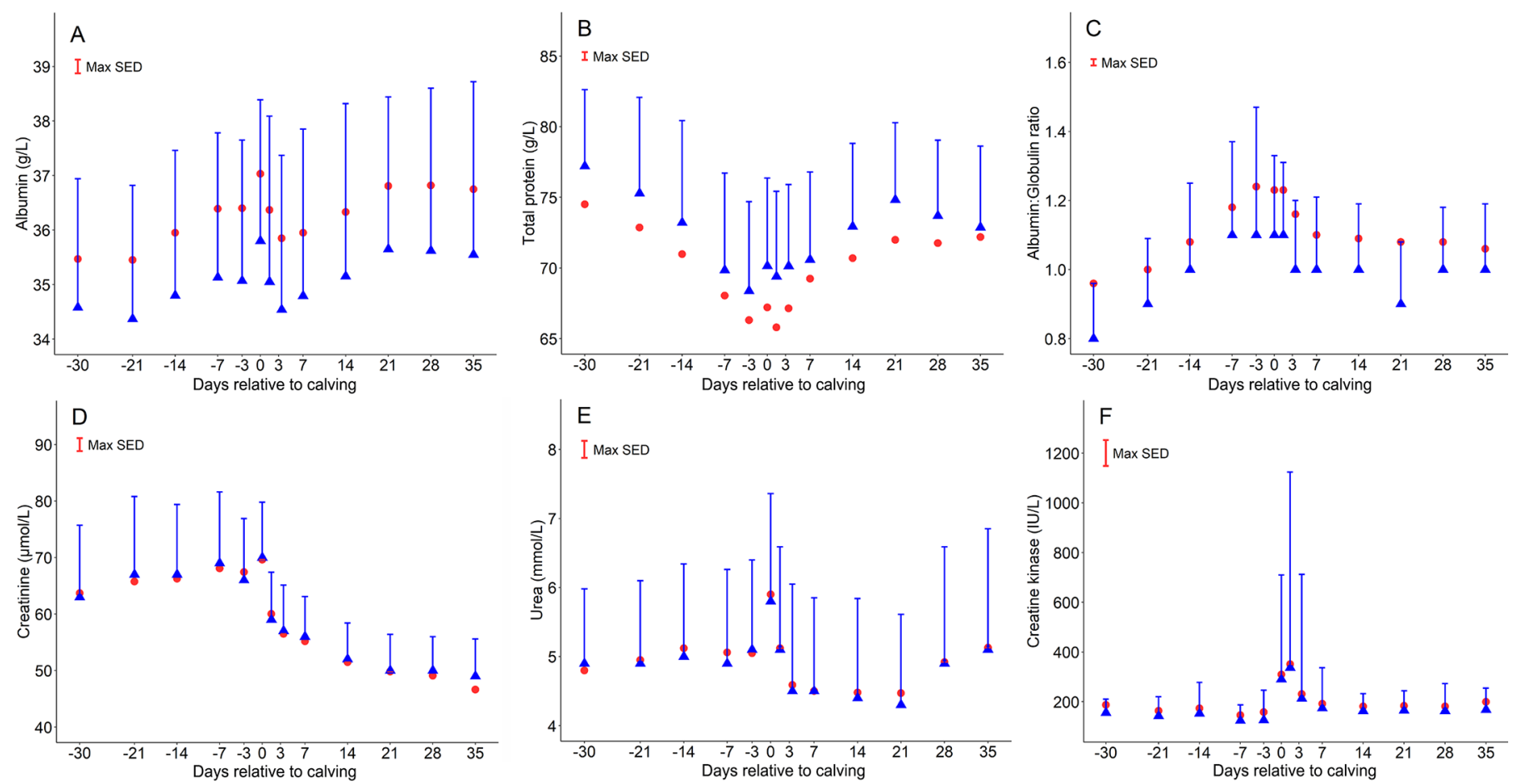

Figure 3. Mean (blue triangles) and upper SD, LSM (red circles), and maximum standard error of the difference (Max SED) for concentrations of protein metabolism analytes. (A) Albumin $(\mathrm{g} / \mathrm{L}),(\mathrm{B})$ total protein $(\mathrm{g} / \mathrm{L}),(\mathrm{C})$ albumin:globulin ratio, $(\mathrm{D}) \mathrm{creatinine}(\mu \mathrm{mol} / \mathrm{L}),(\mathrm{E})$ urea $(\mathrm{mmol} / \mathrm{L})$ and protein metabolism enzyme activities $(\mathrm{F})$ creatine kinase $(\mathrm{IU} / \mathrm{L})$ for the population of grazing dairy cows in the collated database with selected grouped time points by days relative to calving $(\mathrm{d} 0)$. Least squares means for repeated measures model, where variable $=$ breed + parity group + calving season day + grouped day relative to calving (random effect: treatment within experiment; repeated variable $=$ animal number); breed: Holstein-Friesian $(\geq 12 / 16$ ths Holstein-Friesian genetics), Holstein-Friesian $\times$ Jersey crossbred, and Jersey $(\geq 12 / 16$ ths Jersey genetics); parity: group $1=$ parity 1 animals, group $2.5=$ parity 2 and 3 animals, group $5=$ parity 4 to 6 animals, and group $7=$ parity $7+$ animals; calving season day: number of days between June 1 and calving date in the year of calving. $\mathrm{d}-30=30 \mathrm{~d} \pm 5 \mathrm{~d}$ precalving; $\mathrm{d}-21$, $-14,-7=21,14,7 \mathrm{~d} \pm 3 \mathrm{~d}$ precalving; $\mathrm{d}-3=\mathrm{d} 3 \pm 1 \mathrm{~d}$ precalving; $\mathrm{d} 0=\mathrm{d} 1$ precalving and day of calving; $\mathrm{d} 1.5=\mathrm{d} 1$ and 2 postcalving; $\mathrm{d} 3.5=\mathrm{d} 3$ and 4 postcalving; $\mathrm{d} 7,14,21,28,35=7,14,21,28,35 \mathrm{~d} \pm 3 \mathrm{~d}$ postcalving.

LSM of $47 \%$ to $14 \%$ in a linear fashion $(P<0.001)$. In contrast, macrophage \% (Figure 6B) increased 2-fold from $2 \%$ to $4 \%$ between d 14 and $21(P<0.001)$ but decreased thereafter to $1 \%$ by d 35 . Vaginal discharge score (Figure 6C) decreased gradually $(P<0.001)$ over the first 5 wk of lactation, from a mean score of about 2 at d 3.5 to a score of about 1 at d 35 (Table 7).

\section{DISCUSSION}

We present a compilation from 20 experiments spanning almost 20 years, as a comprehensive research data set for temporal profiles of blood analytes for pasturefed transition dairy cows in New Zealand. The data set provides a valuable reference base for various animal health markers of relevance to transition cows in pasture-fed, seasonal-calving dairy systems. Here, we discuss the key temporal trends and range in values observed for various energy, protein, mineral, liver function, inflammation, and uterine and animal health variables in New Zealand pasture-based cows.

\section{Profiles of Energy Metabolism Are Consistent with Uncoupling of the Somatotropic Axis}

The presented profiles of plasma GH and IGF-1, and the associated changes in insulin, NEFA, BHB, BW, and BCS, are consistent with a peripartum uncoupling of the somatotropic axis in anticipation of the energetic demands of lactogenesis and an associated increase in hepatic gluconeogenesis. Postcalving, plasma GH concentrations were greater than precalving, with a concurrent decrease in insulin, glucose, and IGF-1 concentrations in the days immediately following calving. Furthermore, the greater plasma NEFA concentrations represent greater utilization of adipose tissue reserves immediately postcalving, which is reflected in the decrease in BCS and BW (Roche et al., 2009a). The release of GH is pulsatile, and hence, collecting a single blood sample for GH measurement on a particular day may not produce an accurate assessment of the GH status for a particular animal, but in our data set this is mitigated by the large population of animals that had 

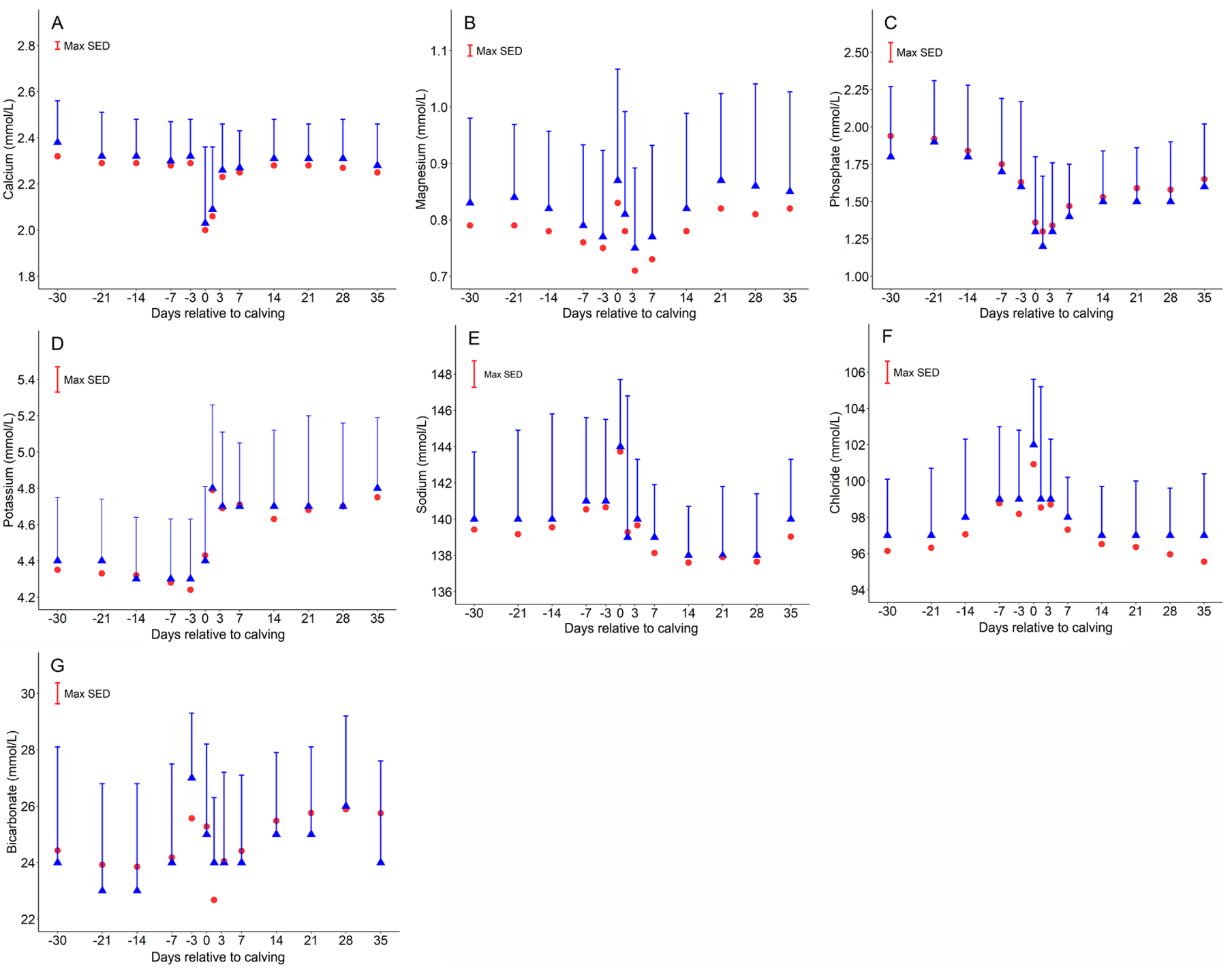

Figure 4. Mean (blue triangles) and upper SD, LSM (red circles), and maximum standard error of the difference (Max SED) for concentrations of mineral balance analytes. (A) Calcium (mmol/L), (B) magnesium (mmol/L), (C) phosphate (mmol/L), (D) potassium (mmol/L), (E) sodium $(\mathrm{mmol} / \mathrm{L}),(\mathrm{F})$ chloride $(\mathrm{mmol} / \mathrm{L})$, and $(\mathrm{G})$ bicarbonate $(\mathrm{mmol} / \mathrm{L})$ for the population of grazing dairy cows in the collated database with selected grouped time points by days relative to calving (d 0$)$. Least squares means for repeated measures model, where variable $=$ breed + parity group + calving season day + grouped day relative to calving (random effect: treatment within experiment; repeated variable $=$ animal number); breed: Holstein-Friesian ( $\geq 12 / 16$ ths Holstein-Friesian genetics), Holstein-Friesian $\times$ Jersey crossbred, and Jersey $(\geq 12 / 16$ ths Jersey genetics); parity: group $1=$ parity 1 animals, group $2.5=$ parity 2 and 3 animals, group $5=$ parity 4 to 6 animals, and group $7=$ parity $7+$ animals; calving season day: number of days between June 1 and calving date in the year of calving. $\mathrm{d}-30=30 \mathrm{~d} \pm 5 \mathrm{~d}$ precalving; $\mathrm{d}-21$, $-14,-7=21,14,7 \mathrm{~d} \pm 3 \mathrm{~d}$ precalving; $\mathrm{d}-3=\mathrm{d} 3 \pm 1 \mathrm{~d}$ precalving; $\mathrm{d} 0=\mathrm{d} 1$ precalving and day of calving; $\mathrm{d} 1.5=\mathrm{d} 1$ and 2 postcalving; $\mathrm{d} 3.5=\mathrm{d} 3$ and 4 postcalving; $\mathrm{d} 7,14,21,28,35=7,14,21,28,35 \mathrm{~d} \pm 3 \mathrm{~d}$ postcalving.

blood samples collected on the same day. The peripartal changes to blood analytes representative of changes in energy balance are well established in dairy cows (Bauman and Currie, 1980; Lucy et al., 2009).

The profile of IGF-1 presented is consistent with other experiments investigating pasture-based cows (Lucy et al., 2009), but the concentration of total IGF1 in circulation is less than many other studies. We would expect the concentrations to be less because of the lack of NFC in the diet (Kolver et al., 2006) and the older age structure of the cows in this study relative to many other studies (Kerr et al., 1991). Plasma concentrations of IGF-1 increase when pasture-fed cows are supplemented with corn silage (Lucy et al., 2009) or a grain-based concentrate feed (Kolver et al., 2006). Some of the difference in reported values, however, may also be a result of differences in laboratory assays and caution is recommended in cross-study comparisons of analyte concentrations. For example, Chanson et al. (2016) reported that different laboratory methods can 
result in concentration differences of $>50 \%$, even when IGF-1 kit manufacturers follow consensus guidelines. Despite the different concentrations produced, however, pairwise concordances were moderate to good. The profile of IGF-1 presented here is consistent with the reported changes in expression of hepatic growth hormone-receptor-1A and IGF-1 in grazing dairy cows (Lucy et al., 2009).

\section{Peripartum Plasma NEFA and BHB Profiles Are Consistent with Profile of BCS Change, But BHB Concentrations Are Greater Than Expected}

Concentrations of NEFA and BHB peaked between d 7 and 14 postcalving, consistent with the maximum rate of BCS loss reported by Roche et al. (2007) from the first derivative of the BCS profile in pasture-based cows. Circulating NEFA concentrations subsequently declined, reflecting a less severe NEB state after wk 2, which, again, is consistent with the first derivative of the BCS curve presented by Roche et al. (2007).
The BHB concentrations were greater than would be anticipated for low to moderate milk production cows consuming TMR with similar NEFA profiles This is not unusual in cows predominantly consuming pasture and should not be confused with metabolically induced hyperketonemia. Roche et al. (2010) reported that circulating BHB concentrations in early-lactation pasture-fed dairy cows were double those of cows fed an isoenergetic equivalent diet, but with $33 \%$ of dietary ME coming from a barley-corn grain concentrate during early lactation; the difference in $\mathrm{BHB}$ was despite similar circulating NEFA concentrations and BCS- and BW-loss profiles. Low to moderate NFC content of the pasture diet $(<15 \%$ DM in spring; Roche et al., 2009b) limits the amount of propionate resulting from microbial fermentation, decreasing the amount of acetyl-CoA entering the tricarboxylic acid cycle (Roche et al., 2009a, 2010). As a result, cellular export of ketone bodies is expected to be increased, thus increasing circulating $\mathrm{BHB}$ concentrations in pasture-fed cows.
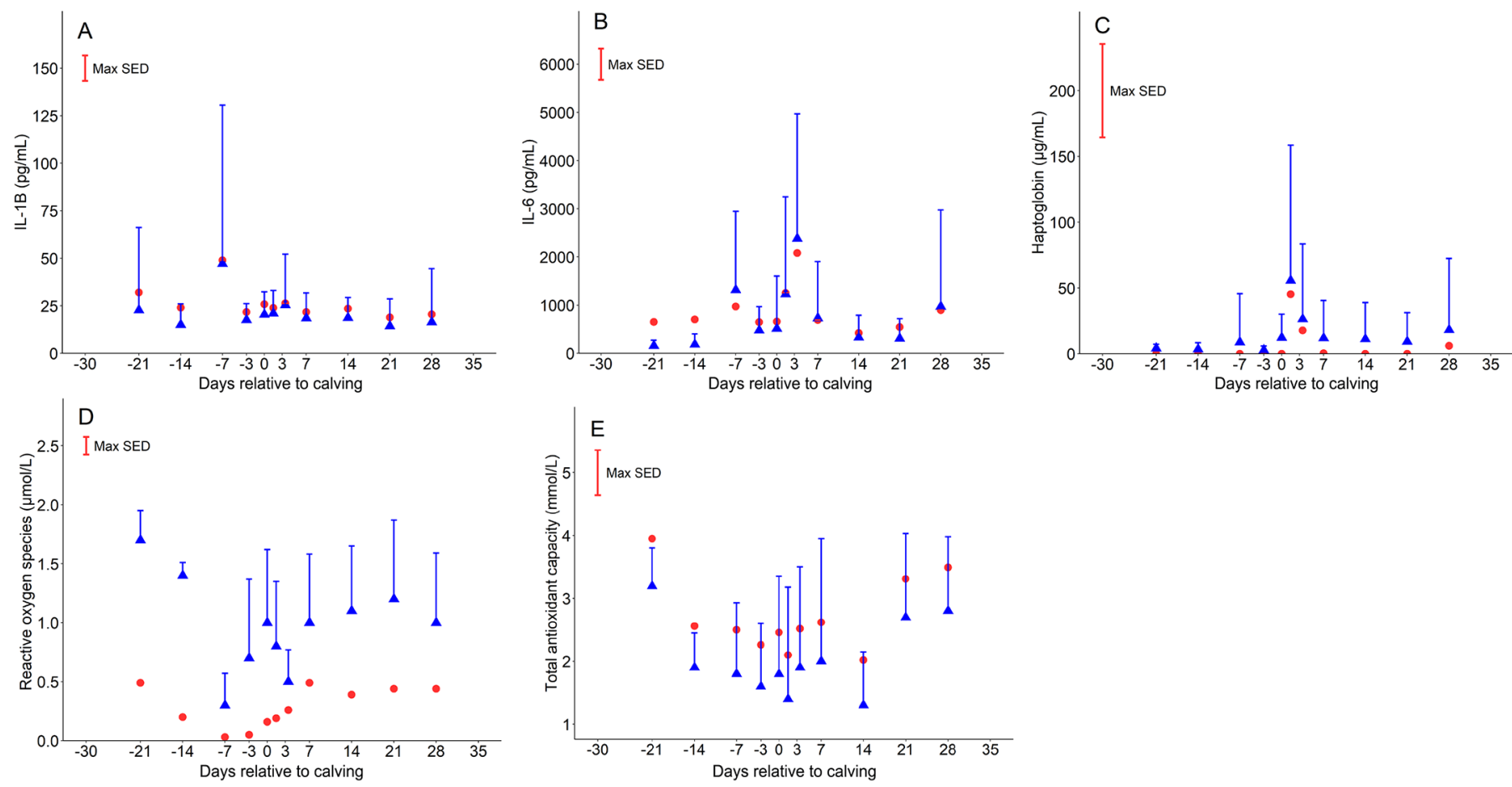

Figure 5. Mean (blue triangles) and upper SD, LSM (red circles), and maximum standard error of the difference (Max SED) for the change in cytokine concentration. (A) Interleukin-1B (pg/mL) and (B) IL-6 (pg/mL), and change in indicators of inflammation analytes, (C) haptoglobin $(\mu \mathrm{g} / \mathrm{mL})$, (D) reactive oxygen species $(\mu \mathrm{mol} / \mathrm{L})$, and $(\mathrm{E})$ total antioxidant capacity $(\mathrm{mmol} / \mathrm{L})$ for the population of grazing dairy cows in the collated database with selected grouped time points by days relative to calving (d 0). Least squares means for repeated measures model, where variable $=$ breed + parity group + calving season day + grouped day relative to calving (random effect: treatment within experiment; repeated variable $=$ animal number $)$; breed: Holstein-Friesian $(\geq 12 / 16$ ths Holstein-Friesian genetics $)$, Holstein-Friesian $\times$ Jersey crossbred, and Jersey ( $\geq 12 / 16$ ths Jersey genetics); parity: group $1=$ parity 1 animals, group $2.5=$ parity 2 and 3 animals, group $5=$ parity 4 to 6 animals, and group $7=$ parity $7+$ animals; calving season day: number of days between June 1 and calving date in the year of calving. $\mathrm{d}-30=30 \mathrm{~d} \pm$ $5 \mathrm{~d}$ precalving; $\mathrm{d}-21,-14,-7=21,14,7 \mathrm{~d} \pm 3 \mathrm{~d}$ precalving; $\mathrm{d}-3=\mathrm{d} 3 \pm 1 \mathrm{~d}$ precalving; $\mathrm{d} 0=\mathrm{d} 1$ precalving and day of calving; $\mathrm{d} 1.5=$ d 1 and 2 postcalving; $\mathrm{d} 3.5=\mathrm{d} 3$ and 4 postcalving; $\mathrm{d} 7,14,21,28,35=7,14,21,28,35 \mathrm{~d} \pm 3 \mathrm{~d}$ postcalving. 

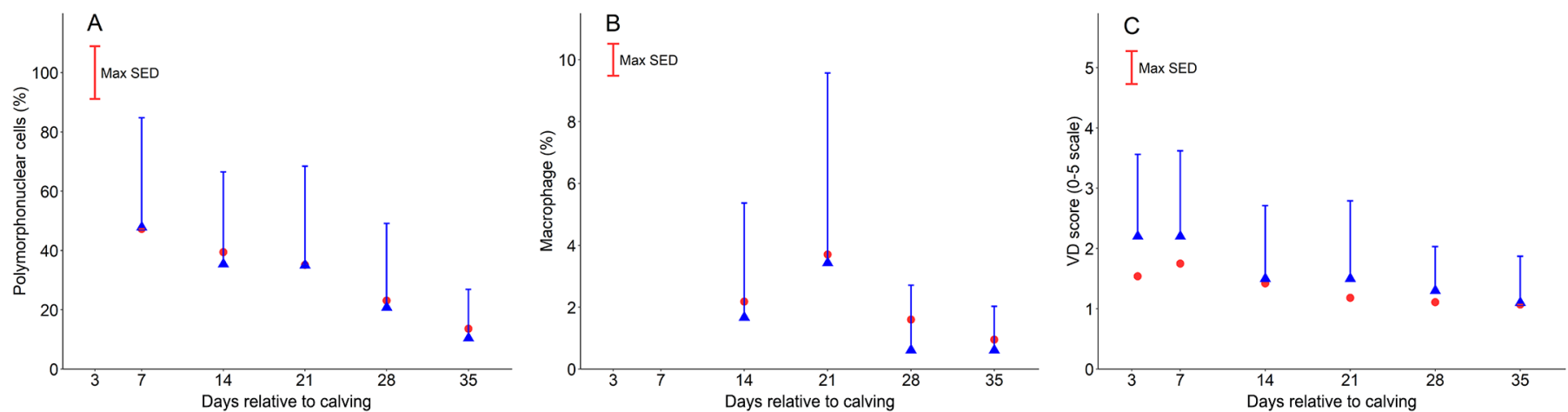

Figure 6. Mean (blue triangles) and upper SD, LSM (red circles), and maximum standard error of the difference (Max SED) for uterine health measures. (A) Polymorphonuclear cells (\%), (B) macrophage (\%), and (C) vaginal discharge (VD) score (0-5 scale) for the population of grazing dairy cows in the collated database with selected grouped time points by days relative to calving (d 0). Least squares means for repeated measures model, where variable $=$ breed + parity group + calving season day + grouped day relative to calving (random effect: treatment within experiment; repeated variable $=$ animal number); breed: Holstein-Friesian $(\geq 12 / 16$ ths Holstein-Friesian genetics $)$, Holstein-Friesian $\times$ Jersey crossbred, and Jersey ( $\geq 12 / 16$ ths Jersey genetics); parity: group $1=$ parity 1 animals, group $2.5=$ parity 2 and 3 animals, group $5=$ parity 4 to 6 animals, and group $7=$ parity $7+$ animals; calving season day: number of days between June 1 and calving date in the year of calving. $\mathrm{d}$ $3.5=\mathrm{d} 3$ and 4 postcalving; $\mathrm{d} 7,14,21,28,35=7,14,21,28,35 \mathrm{~d} \pm 3 \mathrm{~d}$ postcalving.

Despite the greater herd-average BHB concentrations, however, prevalence $(9 \%$; range $2 \%$ at d 0 to $16 \%$ at $\mathrm{d} 7$ ) of postpartum moderate hyperketonemia (BHB $\geq 1.2 \mathrm{mmol} / \mathrm{L}$ ) in the current study was lower than reported for TMR-fed cows (20\% to $58 \%$; Chapinal et al., 2012; McArt et al., 2013a) and similar to the minimum prevalence reported in pasture-fed dairy cows in commercial herds by Compton et al. (2015). The results highlight that cows grazing fresh pasture have greater BHB concentrations than cows consuming TMR, but the effect is likely due to differences in the products of rumen fermentation and incomplete hepatic oxidation of NEFA rather than an indicator of severe NEB.

\section{Liver Activity Is Increased During Early Lactation}

The profiles of circulating liver enzymes and liver TAG indicate increased liver activity and metabolic load during the week immediately following calving. During the transition period, the liver is challenged by the requirement for increased hepatic gluconeogenesis and NEFA oxidation in support of the new lactational state, while at the same time overcoming some degree of hepatic lipidosis as a consequence of lipid mobilization (Lean et al., 2013). In the current study, increases in NEFA concentration began 1 wk precalving, suggesting a change in balance between energy demand and supply, a result of changes in DMI, a gravid uterus at maximum energy and protein requirements (Bell, 1995), mammary development, and colostrogenesis. This is important because the ruminant liver has a limited capacity to export TAG, so hepatic concentrations can become excessive during periods of high NEFA concentration (Grummer, 1993). Decreased circulating bilirubin concentrations, increased AST activity, and increased liver TAG content were also evident during wk 1 following calving, confirming an increased burden on the liver associated with greater lipolysis or a failure to completely oxidize mobilized NEFA, even in moderate-yielding cows.

\section{Inflammation Is Initiated Following Calving}

Peripheral markers of inflammation indicated enhanced activation of the immune system in the days following calving, even in cows displaying no clinical signs of metabolic stress. Inflammation is activated by components of the adaptive and innate immune system in response to stimuli associated with bacterial infection and tissue injury and that trigger coordinated responses (i.e., the acute phase response; APR) to restore homeostasis and destroy pathogens (Bradford et al., 2015; Carneiro et al., 2016). The APR is characterized by increases in positive acute phase proteins (APP), cytokines, and other markers of inflammation, and decreases in negative APP (Bertoni et al., 2008; Trevisi et al., 2010, 2015). Haptoglobin, a commonly measured APP, and IL-6, a less commonly measured cytokine, both increased in circulation in the days immediately following calving, consistent with profiles characterizing the APR in housed cows fed TMR (Humblet et al., 2006; Huzzey et al., 2009; Bossaert et al., 2012). Furthermore, albumin is one of the most commonly measured negative APP, which decreases in concentration due to downregulation of hepatic synthesis, increasing availability of amino acids for the production of positive APP and ensuring osmotic pressure is maintained between the blood vessels and tissues 
(Ceciliani et al., 2012; Trevisi et al., 2015). Presented profiles of albumin were also consistent with an APR in the days immediately following calving, wherein circulating albumin concentrations decreased.

\section{Protein Metabolism and the Potential Role of IL-6 as a Myokine}

The profiles of protein metabolism analytes are indicative of a NEB and concurrent muscle catabolism following calving. Skeletal muscle is affected by homeorhetic changes, whereby protein anabolism is suppressed and catabolism is upregulated; this contributes to a net mobilization of amino acids and decreased muscle fiber diameter in early lactation (Reid et al., 1980; Bell et al., 2000). Skeletal muscle is also considered an endocrine organ, which secretes myokines that include growth factors, cytokines, and peptides that regulate cell proliferation, cell differentiation, and inflammatory pathways (Belizário et al., 2016). For example, IL-6 has been reported as a myokine integral to the APR to exercise in humans, which includes the upregulation of antioxidant defenses in response to oxidative stress (Belizário et al., 2016; Hennigar et al., 2017). We hypothesize that the increase in circulating IL-6 in the days postcalving may be, at least in part, involved in skeletal muscle proteolysis or perhaps uterine involution in the bovine.

The transient increase in CK activity around parturition may be associated with reproductive tract damage that occurs during calving. The activity of CK returns to precalving levels with less variation by $\mathrm{d} 7$, and this is consistent with CK activity presenting as an intermediate indicator of muscular damage that peaks 6 to 12 h later (Pavlata et al., 2001). Generally, CK activity returns to normal values within 24 to $48 \mathrm{~h}$, but persisting muscular damage can result in an extended increase (Pavlata et al., 2001). As there are relatively few studies on CK in cows during the transition period, the profile presented here provides a guide of expected CK concentrations in pasture-fed transition dairy cows.

Postcalving decreases in creatinine concentration in conjunction with decreasing $\mathrm{BCS}$ and $\mathrm{BW}$ throughout the postcalving period are probably indicative of proteolytic processes (Pires et al., 2013; Roche et al., 2013b). Bruckmaier et al. (1998) reported a parallel decrease in plasma creatinine concentration and the diameter of the longissimus dorsi muscle (a measure of muscle mass) following calving. However, the concentration of creatinine in pasture-fed dairy cows presented in the current study was considerably less than reported for TMR-fed cows (Bruckmaier et al., 1998; Bertoni et al., 2008; Turk et al., 2013; Osorio et al., 2014; Megahed et al., 2019). Body weights were not always reported in these previous studies, although mean BW ranged between 675 and $768 \mathrm{~kg}$ precalving and between 659 and $680 \mathrm{~kg}$ postcalving in TMR-fed cows (Bruckmaier et al., 1998; Osorio et al., 2013; Hiew et al., 2016). This is markedly heavier than the 520 to $546 \mathrm{~kg}$ precalving and 455 to $489 \mathrm{~kg}$ postcalving for the cows in the current study. It is plausible that differences in reported creatinine concentrations reflect a lower muscle mass in the cows in the current study compared with heavier TMR-fed cows in other studies.

\section{Mineral Balance Is Affected at Parturition}

Despite the usual tight regulation of plasma mineral concentrations by the kidneys, the peripartum period is characterized by sharp changes in mineral concentrations and critical imbalances in some minerals. Initiation of lactogenesis is the driving factor for changes in $\mathrm{Ca}, \mathrm{PO}_{4}$, and $\mathrm{Mg}$ at calving (DeGaris and Lean, 2008). Prevalence of clinical hypomagnesemia and hypocalcemia was minimal in the current study; however, the prevalence of subclinical states was considerably greater.

Several factors are likely to contribute to hypomagnesemia in the grazing dairy cow: ingestion of pastures rich in $\mathrm{N}$ and $\mathrm{K}$ from applied fertilizers, and high circulating NEFA concentration during early lactation, all of which have an antagonistic effect on circulating $\mathrm{Mg}$; furthermore, inclement weather often reduces DMI, thereby reducing blood $\mathrm{Mg}$ as it is primarily maintained from the diet (Satter and Roche, 2011). Therefore, a common requirement for grazing systems is supplementation of Mg (Satter and Roche, 2011). Prevalence of subclinical hypomagnesemia $(\leq 0.8 \mathrm{mmol} / \mathrm{L})$ ranged between $30.6 \%$ and $63.7 \%$ and for clinical hypomagnesemia $(\leq 0.5 \mathrm{mmol} / \mathrm{L})$ between $1.8 \%$ and $6.2 \%$ during the transition period. The prevalence of subclinical hypomagnesemia is not well characterized in the literature, potentially because it is not a common risk factor in TMR-fed, housed dairy cows. In a retrospective study, Harris et al. (1983) reported annual suspected cases of grass tetany in dairy cows in Victoria, Australia, to be $2.1 \%$; however, no measurements of circulating $\mathrm{Mg}$ were reported, and the data relied on farmer information. Reported mean prevalence of subclinical hypomagnesemia in grazing dairy cows in Brazil was 9.5\% (da Silva et al., 2020) and at calving was $12 \%$ (Masoero et al., 2003). In TMR-fed dairy cows, prevalence has been reported as $7.4 \%$ between calving and d 30 postcalving (Fiorentin et al., 2018) and 4\% between 1 wk pre- to 2 d postcalving (Neves et al., 2017). All of these reported values are considerably lower than in our study, but the previous studies did not use improved temperate pastures accelerated with nitrogen fertilizer; therefore, 
this may be the first study to present the prevalence of subclinical hypomagnesemia in the transition period in a temperate grazing system.

The prevalence of subclinical hypocalcemia in the current study was also considerable (i.e., $35 \%$ of cows had $\leq 2.0 \mathrm{mmol} / \mathrm{L}$ and $60 \%$ had $\leq 2.15 \mathrm{mmol} / \mathrm{L}$ circulating $\mathrm{Ca}$ on the day of calving). A cut point of $2.0 \mathrm{mmol} / \mathrm{L}$ to designate subclinical hypocalcemia indicated it was only materially prevalent at calving, ranging from $2 \%$ to $8 \%$ during the rest of the observational period; this compared with using a cut point of $2.15 \mathrm{mmol} / \mathrm{L}$, which indicated a prevalence of $8 \%$ to $24 \%$ throughout the measurement period. Although the prevalence of subclinical hypocalcemia is more common in the literature, there is still limited information for moderate-yielding dairy cows grazing temperate pastures. In TMR-fed cows, using cut points between 2.0 and $2.4 \mathrm{mmol} / \mathrm{L}$, prevalence ranges from 5 to $66 \%$ (Reinhardt et al., 2011; Neves et al., 2017). In Irish grazing dairy herds, prevalence of milk fever was reported to be 30 to $75 \%$, although the definition of milk fever or the plasma Ca "cut point" used to define the condition were not reported (Mulligan and Doherty, 2008). The prevalence of subclinical hypocalcemia reported here is within the range of previously reported estimates.

Hypomagnesemia has been associated with an increased risk of hypocalcemia, which in turn has been associated with suppressed immune function and increased risk of other production diseases, such as hyperketonemia (Goff, 2008; Reinhardt et al., 2011; Crookenden et al., 2020). In response to lower circulating Ca, parathyroid hormone (PTH) is released from the parathyroid gland, which mobilizes Ca from bone and increases reabsorption in the kidney (Goff, 2008). Magnesium is critical for both PTH release and PTH regulation of the hydroxylation of $1,25-(\mathrm{OH})_{2} \mathrm{D}_{3}$, the active metabolite of vitamin $\mathrm{D}$ that increases intestinal absorption and resorption from bone (DeGaris and Lean, 2008). Therefore, considering the importance of blood $\mathrm{Mg}$ to Ca homeostasis, the seemingly contradictory increase in circulating $\mathrm{Mg}$ concentration at calving when blood $\mathrm{Ca}$ nadirs, as in the presented profile, is likely a natural response to the onset of peripartum hypocalcemia. A lack of response to PTH or $1,25-(\mathrm{OH})_{2} \mathrm{D}_{3}$ has been suggested to be important for the pathogenesis of hypocalcemia, as cows with clinical milk fever have greater concentrations of PTH and $1,25-(\mathrm{OH})_{2} \mathrm{D}_{3}$ than normocalcemic cows (Horst et al., 1978; DeGaris and Lean, 2008). This response is also consistent with the $\mathrm{PO}_{4}$ profiles presented; circulating $\mathrm{PO}_{4}$ concentrations are directly regulated by $1,25-(\mathrm{OH})_{2} \mathrm{D}_{3}$ and indirectly regulated by the $\mathrm{PTH}-\mathrm{Ca}$ negative feedback loop (Goff, 1999). Therefore, the decrease in circulating $\mathrm{PO}_{4}$ at calving, with no change in phosphorus intake, may reflect a decreased intestinal tissue sensitivity to 1,25- $(\mathrm{OH})_{2} \mathrm{D}_{3}$. Circulating concentrations of $\mathrm{Na}, \mathrm{K}$, and $\mathrm{Cl}$ are tightly regulated as the main electrolytes of body fluids (Skrzypczak et al., 2014). The increase in circulating $\mathrm{K}$ concentrations following calving is likely due to the increase in DMI of pasture, as pasture is high in K content (Roche et al., 2009b). On the day of calving, there was a rapid increase in circulating concentrations of $\mathrm{Na}$ and $\mathrm{Cl}$, which rapidly decreased again at the next sampling point. The profiles of $\mathrm{Na}$ and $\mathrm{Cl}$ are very similar, most likely resulting from the electrical neutrality that a 1:1 ratio of $\mathrm{Na}^{+}: \mathrm{Cl}^{-}$provides as blood osmolytes (Skrzypczak et al., 2014). An increase in blood plasma osmotic pressure (i.e., an increase in $\mathrm{Na}$ and $\mathrm{Cl}$ ) has been associated with increased vasopressin and oxytocin on the day of parturition. Vasopressin is secreted from the hypothalamus and aids in water regulation, through action on the kidneys, and elevates blood pressure, through capillary constriction and raising peripheral resistance. Vasopressin secretion is stimulated as blood osmolarity rises. Oxytocin is structurally related to vasopressin and is also involved in the regulation of osmotic pressure. Circulating oxytocin decreases following the expulsion of the placenta, leading to a decrease in the osmotic pressure again (Skrzypczak et al., 2014). Furthermore, data indicate that cows are dehydrated around calving, with electrolyte imbalances (i.e., elevated circulating $\mathrm{Na}$ and $\mathrm{Cl}$ ) exacerbated by a loss of up to $60 \mathrm{~L}$ of uterine fluid at calving (Enemark et al., 2009). Urea was also elevated in circulation on the day of calving in the presented profiles; this might also reflect a reduction in urine output associated with the peripartum dehydration condition (Watford, 2003).

\section{CONCLUSIONS}

Temporal profiles of humoral indicators of metabolic state provide a reference for the expected range in concentration of blood factors associated with energy metabolism, liver function, protein metabolism, mineral status, inflammation, and uterine and animal health during the transition period in pasture-fed dairy cows. The profiles were consistent with expected homeorhetic changes, which reflected a peripartum uncoupling of the somatotropic axis to support lactation, and is accompanied by increases in liver metabolic function, activation of the immune system, and changes in mineral balance. Importantly, however, this is the first time that these profiles have been presented for lowto moderate-yielding grazing dairy cows. The overall general consistency in profile change when compared with higher yielding housed cows fed TMR reflects the "naturalness" or hard-wired nature of the metabolic stress that cows encounter during parturition and is an 
important benchmark for understanding animal physiology in a production setting.

\section{ACKNOWLEDGMENTS}

Funding was provided from contract DRCX1302 to DairyNZ Inc. (Hamilton, New Zealand), a partnership between the New Zealand Ministry of Business, Innovation and Employment (Wellington, New Zealand) and New Zealand dairy farms, as well as the AgResearch Strategic Science Investment (New Zealand) fund. The authors are grateful for the assistance of Carol LeydonDavis, Serena Wang, and Susanne Meier (DairyNZ, Hamilton, New Zealand) in the retrieval of data, along with Julia Lee (DairyNZ, Hamilton, New Zealand) for her collation of the 2000-2006 experimental data. The authors have not stated any conflicts of interest.

\section{REFERENCES}

Bauman, D. E., and W. B. Currie. 1980. Partitioning of nutrients during pregnancy and lactation: A review of mechanisms involving homeostasis and homeorhesis. J. Dairy Sci. 63:1514-1529. https:// doi.org/10.3168/jds.S0022-0302(80)83111-0.

Belizário, J. E., C. C. Fontes-Oliveira, J. P. Borges, J. A. Kashiabara, and E. Vannier. 2016. Skeletal muscle wasting and renewal: A pivotal role of myokine IL-6. Springerplus 5:619. https://doi.org/ 10.1186/s40064-016-2197-2.

Bell, A. W. 1995. Regulation of organic nutrient metabolism during transition from late pregnancy to early lactation. J. Anim. Sci. 73:2804-2819. https://doi.org/10.2527/1995.7392804x.

Bell, A. W., W. S. Burhans, and T. R. Overton. 2000. Protein nutrition in late pregnancy, maternal protein reserves and lactation performance in dairy cows. Proc. Nutr. Soc. 59:119-126. https:// doi.org/10.1017/S0029665100000148.

Bertoni, G., E. Trevisi, X. Han, and M. Bionaz. 2008. Effects of inflammatory conditions on liver activity in puerperium period and consequences for performance in dairy cows. J. Dairy Sci. 91:33003310. https://doi.org/10.3168/jds.2008-0995.

Bobe, G., J. W. Young, and D. C. Beitz. 2004. Invited Review: Pathology, etiology, prevention, and treatment of fatty liver in dairy cows. J. Dairy Sci. 87:3105-3124. https://doi.org/10.3168/jds .S0022-0302(04)73446-3.

Bogado Pascottini, O., and S. J. LeBlanc. 2020. Metabolic markers for purulent vaginal discharge and subclinical endometritis in dairy cows. Theriogenology 155:43-48. https://doi.org/10.1016/j theriogenology.2020.06.005.

Bossaert, P., E. Trevisi, G. Opsomer, G. Bertoni, S. De Vliegher, and J. L. M. R. Leroy. 2012. The association between indicators of inflammation and liver variables during the transition period in high-yielding dairy cows: An observational study. Vet. J. 192:222225. https://doi.org/10.1016/j.tvjl.2011.06.004.

Bradford, B. J., and T. H. Swartz. 2020. Review: Following the smoke signals: Inflammatory signaling in metabolic homeostasis and homeorhesis in dairy cattle. Animal 14:s144-s154. https://doi.org/10 $.1017 /$ S1751731119003203.

Bradford, B. J., K. Yuan, J. K. Farney, L. K. Mamedova, and A. J. Carpenter. 2015. Invited review: Inflammation during the transition to lactation: New adventures with an old flame. J. Dairy Sci. 98:6631-6650. https://doi.org/10.3168/jds.2015-9683.

Bruckmaier, R. M., L. Gregoretti, F. Jans, D. Faissler, and J. W. Blum. 1998. Longissimus dorsi muscle diameter, backfat thickness, body condition scores and skinfold values related to metabolic and endocrine traits in lactating dairy cows fed crystalline fat or free fatty acids. J. Vet. Med. A Physiol. Pathol. Clin. Med. 45:397-410. https://doi.org/10.1111/j.1439-0442.1998.tb00842.x.

Burke, C. R., J. K. Kay, C. V. C. Phyn, S. Meier, J. M. Lee, and J. R. Roche. 2010. Short communication: Effects of dietary nonstructural carbohydrates pre- and postpartum on reproduction of grazing dairy cows. J. Dairy Sci. 93:4292-4296. https://doi.org/10 $.3168 /$ jds.2009-2869.

Burke, C. R., and J. R. Roche. 2007. Effects of pasture feeding during the periparturient period on postpartum anovulation in grazed dairy cows. J. Dairy Sci. 90:4304-4312. https://doi.org/10.3168/ jds.2006-788.

Burke, C. R., J. R. Roche, P. W. Aspin, and J. M. Lee. 2006. A nutrient-signalling effect of grain feeding on postpartum anovulatory intervals in mature dairy cows. Proc. N.Z. Soc. Anim. Prod. 66:334-338.

Carneiro, L. C., J. G. Cronin, and I. M. Sheldon. 2016. Mechanisms linking bacterial infections of the bovine endometrium to disease and infertility. Reprod. Biol. 16:1-7. https://doi.org/10.1016/j .repbio.2015.12.002.

Ceciliani, F., J. J. Ceron, P. D. Eckersall, and H. Sauerwein. 2012. Acute phase proteins in ruminants. J. Proteomics 75:4207-4231. https://doi.org/10.1016/j.jprot.2012.04.004.

Chanson, P., A. Arnoux, M. Mavromati, S. Brailly-Tabard, C. Massart, J. Young, M. Piketty, and J.-C. Souberbielle. 2016. Reference Values for IGF-I Serum Concentrations: Comparison of Six Immunoassays. J. Clin. Endocrinol. Metab. 101:3450-3458. https://doi .org/10.1210/jc.2016-1257.

Chapinal, N., M. Carson, T.F. Duffield, M. Capel, S. Godden, M. Overton, J.E.P. Santos, and S.J. LeBlanc. 2011. the association of serum metabolites with clinical disease during the transition period 4897-4903. https://doi.org/10.3168/jds.2010-4075.

Chapinal, N., M. E. Carson, S. J. LeBlanc, K. E. Leslie, S. Godden, M. Capel, J. E. P. Santos, M. W. Overton, and T. F. Duffield. 2012 The association of serum metabolites in the transition period with milk production and early-lactation reproductive performance. J. Dairy Sci. 95:1301-1309. https://doi.org/10.3168/jds.2011-4724.

Compton, C. W. R., L. Young, and S. McDougall. 2015. Subclinical ketosis in post-partum dairy cows fed a predominantly pasturebased diet: Defining cut-points for diagnosis using concentrations of beta-hydroxybutyrate in blood and determining prevalence. N. Z. Vet. J. 63:241-248. https://doi.org/10.1080/00480169.2014 .999841.

Crookenden, M. A., A. Heiser, A. Murray, V. S. R. Dukkipati, J. K. Kay, J. J. Loor, S. Meier, M. D. Mitchell, K. M. Moyes, C. G. Walker, and J. R. Roche. 2016a. Parturition in dairy cows temporarily alters the expression of genes in circulating neutrophils. J. Dairy Sci. 99:6470-6483. https://doi.org/10.3168/jds.2015-10877.

Crookenden, M. A., K. M. Moyes, B. Kuhn-Sherlock, K. Lehnert, C. G. Walker, J. J. Loor, M. D. Mitchell, A. Murray, V. S. R. Dukkipati, M. Vailati-Riboni, A. Heiser, and J. R. Roche. 2019. Transcriptomic analysis of circulating neutrophils in metabolically stressed peripartal grazing dairy cows. J. Dairy Sci. 102:7408-7420. https:/ /doi.org/10.3168/jds.2019-16367.

Crookenden, M. A., C. V. C. Phyn, S. A. Turner, J. J. Loor, A. I. Smith, V. Lopreiato, C. R. Burke, A. Heiser, and J. R. Roche. 2020. Feeding synthetic zeolite to transition dairy cows alters neutrophil gene expression. J. Dairy Sci. 103:723-736. https://doi .org/10.3168/jds.2019-17097.

Crookenden, M. A., J. R. Roche, A. Heiser, B. Kuhn-Sherlock, C. D. Higham, C. V. C. Phyn, and S.-A. Turner. 2021. Effect of dose rate and timing of administration of pegbovigrastim on white blood cell responses in grazing dairy cows. J. Dairy Sci. 104:11955-11972. https://doi.org/10.3168/jds.2021-20630.

Crookenden, M. A., C. G. Walker, H. Peiris, Y. Koh, A. Heiser, J. J. Loor, K. M. Moyes, A. Murray, V. S. R. Dukkipati, J. K. Kay, S. Meier, J. R. Roche, and M. D. Mitchell. 2016b. Short communication: Proteins from circulating exosomes represent metabolic state in transition dairy cows. J. Dairy Sci. 99:7661-7668. https://doi .org/10.3168/jds.2015-10786.

da Silva, D. C., B. D. Fernandes, J. M. dos Santos Lima, B. A. da Silva, G. P. Rodrigues, and E. J. O. de Souza. 2020. Subclinical 
hypomagnesemia: Prevalence and causes in dairy cows in the semiarid region of the state of Paraiba, Brazil. Rev. Bras. Saúde Prod. Anim. 21:1-13. https://doi.org/10.1590/s1519-99402121132020.

DeGaris, P. J., and I. J. Lean. 2008. Milk fever in dairy cows: A review of pathophysiology and control principles. Vet. J. 176:58-69. https: //doi.org/10.1016/j.tvjl.2007.12.029.

Enemark, J. M. D., H. B. Schmidt, J. Jakobsen, and C. Enevoldsen. 2009. Failure to improve energy balance or dehydration by drenching transition cows with water and electrolytes at calving. Vet. Res. Commun. 33:123-137. https://doi.org/10.1007/s11259-008 $-9079-1$.

Fiorentin, E. L., S. Zanovello, A. Gato, A. L. Piovezan, M. V. Alves, R. X. Rocha, and F. Gonzalez. 2018. Occurrence of subclinical metabolic disorders in dairy cows from western Santa Catarina state, Brazil. Pesqui. Vet. Bras. 38:629-634. https://doi.org/10 $.1590 / 1678-5150-$ pvb-5156.

Goff, J. P. 1999. Treatment of calcium, phosphorus, and magnesium balance disorders. Vet. Clin. North Am. Food Anim. Pract. 15:619-639. https://doi.org/10.1016/S0749-0720(15)30167-5.

Goff, J. P. 2008. The monitoring, prevention, and treatment of milk fever and subclinical hypocalcemia in dairy cows. Vet. J. 176:50-57. https://doi.org/10.1016/j.tvjl.2007.12.020.

Grala, T. M., R. R. Handley, J. R. Roche, C. G. Walker, C. V. C. Phyn, and J. K. Kay. 2016. Once-daily milking during late lactation in pasture-fed dairy cows has minor effects on feed intake, body condition score gain, and hepatic gene expression. J. Dairy Sci. 99:3041-3055. https://doi.org/10.3168/jds.2015-10412.

Grala, T. M., J. K. Kay, C. G. Walker, A. J. Sheahan, M. D. Littlejohn, M. C. Lucy, and J. R. Roche. 2010. Expression analysis of key somatotropic axis and liporegulatory genes in ghrelin- and obestatin-infused dairy cows. Domest. Anim. Endocrinol. 39:7683. https://doi.org/10.1016/j.domaniend.2010.02.004.

Grala, T. M., B. Kuhn-Sherlock, J. R. Roche, O. M. Jordan, C. V. C. Phyn, C. R. Burke, and S. Meier. 2022. Changes in plasma electrolytes, minerals, and hepatic markers of health across the transition period in dairy cows divergent in genetic merit for fertility traits and postpartum anovulatory intervals. J. Dairy Sci. 105:XXXXXX. https://doi.org/10.3168/jds.2021-20783.

Grala, T. M., C. V. C. Phyn, J. K. Kay, A. G. Rius, M. C. Lucy, M. D. Littlejohn, R. G. Snell, and J. R. Roche. 2014a. Gene expression in liver and adipose tissue is altered during and after temporary changes to postpartum milking frequency. J. Dairy Sci. 97:27012717. https://doi.org/10.3168/jds.2013-7024.

Grala, T. M., C. V. C. Phyn, J. K. Kay, A. G. Ruis, M. D. Littlejohn, R. G. Snell, and J. R. Roche. 2011. Temporary alterations to milking frequency immediately post-calving modified the expression of genes regulating milk synthesis and apoptosis in the bovine mammary gland. Proc. N.Z. Soc. Anim. Prod. 71:3-8.

Grala, T. M., J. R. Roche, J. K. Kay, A. G. Rius, H. M. White, S. S. Donkin, M. D. Littlejohn, R. G. Snell, and C. V. C. Phyn. 2014b. The expression of genes involved in hepatic metabolism is altered by temporary changes to milking frequency. J. Dairy Sci. 97:838-850. https://doi.org/10.3168/jds.2013-7321.

Grummer, R. R. 1993. Etiology of lipid-related metabolic disorders in periparturient dairy cows. J. Dairy Sci. 76:3882-3896. https://doi .org/10.3168/jds.S0022-0302(93)77729-2.

Harris, D. J., R. G. Lambell, and C. J. Oliver. 1983. Factors predisposing dairy and beef cows to grass tetany. Aust. Vet. J. 60:230-234. https://doi.org/10.1111/j.1751-0813.1983.tb05970.x.

Heiser, A., A. Mccarthy, N. Wedlock, S. Meier, J. Kay, C. Walker, M. A. Crookenden, M. D. Mitchell, S. Morgan, K. Watkins, J. J. Loor, and J. R. Roche. 2015. Grazing dairy cows had decreased interferon- $\gamma$, tumour necrosis factor, and interleukin-17, and increased expression of interleukin-10 during the first week after calving. J. Dairy Sci. 98:937-946. https://doi.org/10.3168/jds .2014-8494.

Hennigar, S. R., J. P. McClung, and S. M. Pasiakos. 2017. Nutritional interventions and the IL-6 response to exercise. FASEB J. 31:3719-3728. https://doi.org/10.1096/fj.201700080R.

Hiew, M. W. H., A. A. Megahed, J. R. Townsend, W. L. Singleton, and P. D. Constable. 2016. Clinical utility of calf front hoof circumfer- ence and maternal intrapelvic area in predicting dystocia in 103 late gestation Holstein-Friesian heifers and cows. Theriogenology 85:384-395. https://doi.org/10.1016/j.theriogenology.2015.08.017.

Horst, R. L., H. F. Deluca, and N. A. Jorgensen. 1978. The effect of age on calcium absorption and accumulation of 1,25-dihydroxyvitamin D3 in intestinal mucosa of rats. Metab. Bone Dis. Relat. Res. 1:29-33. https://doi.org/10.1016/0221-8747(78)90033-4.

Humblet, M. F., H. Guyot, B. Boudry, F. Mbayahi, C. Hanzen, F. Rollin, and J. M. Godeau. 2006. Relationship between haptoglobin, serum amyloid A, and clinical status in a survey of dairy herds during a 6-month period. Vet. Clin. Pathol. 35:188-193. https:// doi.org/10.1111/j.1939-165X.2006.tb00112.x.

Huzzey, J. M., T. F. Duffield, S. J. LeBlanc, D. M. Veira, D. M. Weary, and M. A. G. Von Keyserlingk. 2009. Short communication: Haptoglobin as an early indicator of metritis. J. Dairy Sci. 92:621-625. https://doi.org/10.3168/jds.2008-1526.

Ingvartsen, K. L. 2006. Feeding- and management-related diseases in the transition cow: Physiological adaptations around calving and strategies to reduce feeding-related diseases. Anim. Feed Sci. Technol. 126:175-213. https://doi.org/10.1016/j.anifeedsci.2005 .08 .003 .

Kay, J. K., J. R. Roche, C. E. Moore, and L. H. Baumgard. 2006. Effects of dietary conjugated linoleic acid on production and metabolic parameters in transition dairy cows grazing fresh pasture. J. Dairy Res. 73:367-377. https://doi.org/10.1017/S0022029906001944.

Kerr, D. E., J. G. Manns, B. Laarveld, and M. I. Fehr. 1991. Profiles of serum IGF-I concentrations in calves from birth to eighteen months of age and in cows throughout the lactation cycle. Can. J. Anim. Sci. 71:695-705. https://doi.org/10.4141/cjas91-085.

Kolver, E. S., J. R. Roche, and P. W. Aspin. 2006. Plasma insulin, growth hormone, and IGF-1 concentrations of Holstein-Friesian cows of divergent genotype offered varying levels of concentrate in early lactation. Proc. N.Z. Soc. Anim. Prod. 66:403-408.

Kolver, E. S., J. R. Roche, C. R. Burke, and P. W. Aspin. 2005. Influence of dairy cow genotype on milksolids, body condition and reproduction response to concentrate supplementation. NZ Soc Anim Prod Proc 65:46-52.

Kolver, E. S., J. R. Roche, M. J. de Veth, P. L. Thorne, and A. R. Napper. 2002. Total mixed rations versus pasture diets: Evidence for a genotype $\mathrm{x}$ diet interaction in dairy cow performance. Proc. N.Z. Soc. Anim. Prod. 62:246-251.

Lange, J., S. Ganesh, S. Meier, J. K. Kay, M. A. Crookenden, C. G. Walker, M. D. Mitchell, J. J. Loor, J. R. Roche, and A. Heiser. 2019. Far-off and close-up feeding levels affect immunological performance in grazing dairy cows during the transition period. J. Anim. Sci. 97:192-207. https://doi.org/10.1093/jas/sky427.

Lange, J., A. McCarthy, J. Kay, S. Meier, C. Walker, M. A. Crookenden, M. D. Mitchell, J. J. Loor, J. R. Roche, and A. Heiser. 2016. Prepartum feeding level and body condition score affect immunological performance in grazing dairy cows during the transition period. J. Dairy Sci. 99:2329-2338. https://doi.org/10.3168/ jds.2015-10135.

Lean, I. J., R. van Saun, and P. J. DeGaris. 2013. Energy and protein nutrition management of transition dairy cows. Vet. Clin. North Am. Food Anim. Pract. 29:337-366. https://doi.org/10.1016/j .cvfa.2013.03.005.

LeBlanc, S. J., K. E. Leslie, and T. F. Duffield. 2005. Metabolic predictors of displaced abomasum in dairy cattle. J. Dairy Sci. 88:159-170. https://doi.org/10.3168/jds.S0022-0302(05)72674-6.

Lucy, M. C., G. A. Verkerk, B. E. Whyte, K. A. Macdonald, L. Burton, R. T. Cursons, J. R. Roche, and C. W. Holmes. 2009. Somatotropic axis components and nutrient partitioning in genetically diverse dairy cows managed under different feed allowances in a pasture system. J. Dairy Sci. 92:526-539. https://doi.org/10.3168/ jds.2008-1421.

Macdonald, K. A., D. Beca, J. W. Penno, J. A. S. Lancaster, and J. R. Roche. 2011. Short communication: Effect of stocking rate on the economics of pasture-based dairy farms. J. Dairy Sci. 94:25812586. https://doi.org/10.3168/jds.2010-3688.

Macdonald, K. A., C. B. Glassey, and R. P. Rawnsley. 2010. The emergence, development and effectiveness of decision rules for pas- 
ture based dairy systems. Pages 199-209 in Proceedings of the 4th Australasian Dairy Science Symposium. Caxton Press.

Macdonald, K. A., J. W. Penno, J. A. S. Lancaster, and J. R. Roche. 2008. Effect of stocking rate on pasture production, milk production, and reproduction of dairy cows in pasture-based systems. J. Dairy Sci. 91:2151-2163. https://doi.org/10.3168/jds.2007-0630.

Macdonald, K. A., J. W. Penno, P. K. Nicholas, J. A. Lile, M. Coulter, and J. A. S. Lancaster. 2001. Farm systems-Impact of stocking rate on dairy farm efficiency. Proc. N. Z. Grassl. Assoc. 63:223227. https://doi.org/10.33584/jnzg.2001.63.2403.

Masoero, F., M. Moschini, and A. M. Pulimeno. 2003. Serum calcium and magnesium level in dairy cows at calving. Ital. J. Anim. Sci. $2: 172-174$.

McArt, J. A. A., and R. C. Neves. 2020. Association of transient, persistent, or delayed subclinical hypocalcemia with early lactation disease, removal, and milk yield in Holstein cows. J. Dairy Sci. 103:690-701. https://doi.org/10.3168/jds.2019-17191.

McArt, J. A. A., D. V. Nydam, and G. R. Oetzel. 2013a. Dry period and parturient predictors of early lactation hyperketonemia in dairy cattle. J. Dairy Sci. 96:198-209. https://doi.org/10.3168/ jds.2012-5681.

McArt, J. A. A., D. V. Nydam, G. R. Oetzel, T. R. Overton, and P. A. Ospina. 2013b. Elevated non-esterified fatty acids and $\beta$-hydroxybutyrate and their association with transition dairy cow performance. Vet. J. 198:560-570. https://doi.org/10.1016/j.tvjl .2013.08.011

McDougall, S., D. Aberdein, A. Bates, and C. R. Burke. 2020. Prevalence of endometritis diagnosed by vaginal discharge scoring or uterine cytology in dairy cows and herds. J. Dairy Sci. 103:65116521. https://doi.org/10.3168/jds.2019-18048.

Megahed, A. A., M. W. H. Hiew, D. Ragland, and P. D. Constable. 2019. Changes in skeletal muscle thickness and echogenicity and plasma creatinine concentration as indicators of protein and intramuscular fat mobilization in periparturient dairy cows. J. Dairy Sci. 102:5550-5565. https://doi.org/10.3168/jds.2018-15063.

Meier, S., B. Fisher, K. Eketone, L. R. McNaughton, P. A. Amer, P. Beatson, J. R. Bryant, K. G. Dodds, R. Spelman, J. R. Roche, and C. R. Burke. 2017. Calf and heifer development and the onset of puberty in dairy cows with divergent genetic merit for fertility. New Zeal. Soc. Anim. Prod. 77:205-210.

Meier, S., L. R. Mcnaughton, R. Handcock, P. R. Amer, P. R. Beatson, J. R. Bryant, K. G. Dodds, R. Spelman, J. R. Roche, and C. R. Burke. 2021. Heifers with positive genetic merit for fertility traits reach puberty earlier and have a greater pregnancy rate than heifers with negative genetic merit for fertility traits. J. Dairy Sci. 104:3707-3721. https://doi.org/10.3168/jds.2020-19155.

Meier, S., N. V. Priest, C. R. Burke, J. K. Kay, S. McDougall, M. D. Mitchell, C. G. Walker, A. Heiser, J. J. Loor, and J. R. Roche. 2014. Treatment with a nonsteroidal antiinflammatory drug after calving did not improve milk production, health, or reproduction parameters in pasture-grazed dairy cows. J. Dairy Sci. 97:29322943. https://doi.org/10.3168/jds.2013-7838.

Ministry for Primary Industries. 1999. Use of Animals in Research, Testing and Teaching. Accessed Nov. 5, 2021. https://www .legislation.govt.nz/act/public/1999/0142/latest/DLM49664.html.

Mulligan, F. J., and M. L. Doherty. 2008. Production diseases of the transition cow. Vet. J. 176:3-9. https://doi.org/10.1016/j.tvjl.2007 .12 .018 .

Neves, R. C., B. M. Leno, K. D. Bach, and J. A. A. McArt. 2018. Epidemiology of subclinical hypocalcemia in early-lactation Holstein dairy cows: The temporal associations of plasma calcium concentration in the first 4 days in milk with disease and milk production. J. Dairy Sci. 101:9321-9331. https://doi.org/10.3168/ jds.2018-14587.

Neves, R. C., B. M. Leno, T. Stokol, T. R. Overton, and J. A. A. McArt. 2017. Risk factors associated with postpartum subclinical hypocalcemia in dairy cows. J. Dairy Sci. 100:3796-3804. https:// doi.org/10.3168/jds.2016-11970.

Oetzel, G. R. 2004. Monitoring and testing dairy herds for metabolic disease. Vet. Clin. North Am. Food Anim. Pract. 20:651-674. https://doi.org/10.1016/j.cvfa.2004.06.006.
Osorio, J. S., P. Ji, J. K. Drackley, D. Luchini, and J. J. Loor. 2013. Supplemental Smartamine M or MetaSmart during the transition period benefits postpartal cow performance and blood neutrophil function. J. Dairy Sci. 96:6248-6263. https://doi.org/10.3168/jds .2012-5790.

Osorio, J. S., E. Trevisi, P. Ji, J. K. Drackley, D. Luchini, G. Bertoni, and J. J. Loor. 2014. Biomarkers of inflammation, metabolism, and oxidative stress in blood, liver, and milk reveal a better immunometabolic status in peripartal cows supplemented with Smartamine M or MetaSmart. J. Dairy Sci. 97:7437-7450. https://doi .org/10.3168/jds.2013-7679.

Ospina, P. A., J. A. McArt, T. R. Overton, T. Stokol, and D. V. Nydam. 2013. Using nonesterified fatty acids and B-hydroxybutyrate concentrations during the transition period for herd-level monitoring of increased risk of disease and decreased reproductive and milking performance. Vet. Clin. North Am. Food Anim. Pract. 29:387-412. https://doi.org/10.1016/j.cvfa.2013.04.003.

Ospina, P. A., D. V. Nydam, T. Stokol, and T. R. Overton. 2010a. Associations of elevated nonesterified fatty acids and $\beta$-hydroxybutyrate concentrations with early lactation reproductive performance and milk production in transition dairy cattle in the northeastern United States. J. Dairy Sci. 93:1596-1603. https: //doi.org/10.3168/jds.2009-2852.

Ospina, P. A., D. V. Nydam, T. Stokol, and T. R. Overton. 2010b. Evaluation of nonesterified fatty acids and $\beta$-hydroxybutyrate in transition dairy cattle in the northeastern United States: Critical thresholds for prediction of clinical diseases. J. Dairy Sci. 93:546554. https://doi.org/10.3168/jds.2009-2277.

Pavlata, L., A. Pechova, and J. Illek. 2001. Muscular dystrophy in dairy cows following a change in housing technology. Acta Vet. Brno 70:269-275. https://doi.org/10.2754/avb200170030269.

Phyn, C. V. C., J. K. Kay, A. G. Rius, S. R. Morgan, C. G. Roach, T. M. Grala, and J. R. Roche. 2014. Temporary alterations to postpartum milking frequency affect whole-lactation milk production and the energy status of pasture-grazed dairy cows. J. Dairy Sci. 97:6850-6868. https://doi.org/10.3168/jds.2013-7836.

Phyn, C. V. C., J. K. Kay, A. G. Rius, S. R. Morgan, C. S. Roach, T. M. Grala, and J. R. Roche. 2011. Effect of temporary alterations to milking frequency during the early post-partum period on milk production and body condition score in grazing dairy cows. Proc. N.Z. Soc. Anim. Prod. 71:45-49.

Pires, J. A. A., C. Delavaud, Y. Faulconnier, D. Pomiès, and Y. Chilliard. 2013. Effects of body condition score at calving on indicators of fat and protein mobilization of periparturient Holstein-Friesian cows. J. Dairy Sci. 96:6423-6439. https://doi.org/10.3168/jds.2013 $-6801$.

Priest, N. V., S. McDougall, C. R. Burke, J. R. Roche, M. D. Mitchell, K. L. McLeod, S. L. Greenwood, and S. Meier. 2013. The responsiveness of subclinical endometritis to a nonsteroidal antiinflammatory drug in pasture-grazed dairy cows. J. Dairy Sci. 96:4323-4332. https://doi.org/10.3168/jds.2012-6266.

Reid, B. Y. I. M., C. J. Roberts, and G. D. Baird. 1980. The effects of underfeeding during pregnancy and lactation on structure and chemistry of bovine liver and muscle. J. Agric. Sci. 94:239-245. https://doi.org/10.1017/S0021859600028100.

Reinhardt, T. A., J. D. Lippolis, B. J. McCluskey, J. P. Goff, and R. L. Horst. 2011. Short Communication: Prevalence of subclinical hypocalcemia in dairy herds. Vet. J. 188:122-124. https://doi.org/ 10.1016/j.tvjl.2010.03.025.

Roche, J. R. 2007. Milk production responses to pre- and postcalving dry matter intake in grazing dairy cows. Livest. Sci. 110:12-24. https://doi.org/10.1016/j.livsci.2006.08.016.

Roche, J. R., D. P. Berry, and E. S. Kolver. 2006a. Holstein-Friesian strain and feed effects on milk production, body weight, and body condition score profiles in grazing dairy cows. J. Dairy Sci 89:3532-3543. https://doi.org/10.3168/jds.S0022-0302(06)72393 $-1$.

Roche, J. R., D. P. Berry, J. M. Lee, K. A. Macdonald, and R. C. Boston. 2007. Describing the body condition score change between successive calvings: A novel strategy generalizable to diverse co- 
horts. J. Dairy Sci. 90:4378-4396. https://doi.org/10.3168/jds 2006-729.

Roche, J. R., P. G. Dillon, C. R. Stockdale, L. H. Baumgard, and M. J. VanBaale. 2004. Relationships among international body condition scoring systems. J. Dairy Sci. 87:3076-3079. https://doi.org/ 10.3168/jds.S0022-0302(04)73441-4.

Roche, J. R., N. C. Friggens, J. K. Kay, M. W. Fisher, K. J. Stafford, and D. P. Berry. 2009a. Invited review: Body condition score and its association with dairy cow productivity, health, and welfare. J. Dairy Sci. 92:5769-5801. https://doi.org/10.3168/jds.2009-2431.

Roche, J. R., A. Heiser, M. D. Mitchell, M. A. Crookenden, C. G. Walker, J. K. Kay, M. V. Riboni, J. J. Loor, and S. Meier. 2017a. Strategies to gain body condition score in pasture-based dairy cows during late lactation and the far-off nonlactating period and their interaction with close-up dry matter intake. J. Dairy Sci. 100:1720-1738. https://doi.org/10.3168/jds.2016-11591.

Roche, J. R., J. K. Kay, N. C. Friggens, J. J. Loor, and D. P. Berry. 2013a. Assessing and managing body condition score for the prevention of metabolic disease in dairy cows. Vet. Clin. North Am. Food Anim. Pract. 29:323-336. https://doi.org/10.1016/j.cvfa 2013.03.003.

Roche, J. R., J. K. Kay, C. V. C. Phyn, S. Meier, J. M. Lee, and C. R. Burke. 2010. Dietary structural to nonfiber carbohydrate concentration during the transition period in grazing dairy cows. J. Dairy Sci. 93:3671-3683. https://doi.org/10.3168/jds.2009-2868.

Roche, J. R., E. S. Kolver, and J. K. Kay. 2005. Influence of precalving feed allowance on periparturient metabolic and hormonal responses and milk production in grazing dairy cows. J. Dairy Sci. 88:677-689. https://doi.org/10.3168/jds.S0022-0302(05)72732-6.

Roche, J. R., J. M. Lee, P. W. Aspin, A. J. Sheahan, C. R. Burke, E. S. Kolver, B. Sugar, and A. R. Napper. 2006b. Supplementation with concentrates either pre- or post-partum does not affect milk production when diets are iso-energetic. Proc. N.Z. Soc. Anim. Prod. 66:416-422.

Roche, J. R., K. A. Macdonald, K. E. Schütz, L. R. Matthews, G. A. Verkerk, S. Meier, J. J. Loor, A. R. Rogers, J. McGowan, S. R. Morgan, S. Taukiri, and J. R. Webster. 2013b. Calving body condition score affects indicators of health in grazing dairy cows. J. Dairy Sci. 96:5811-5825. https://doi.org/10.3168/jds.2013-6600.

Roche, J. R., S. Meier, A. Heiser, M. D. Mitchell, C. G. Walker, M. A. Crookenden, M. V. Riboni, J. J. Loor, and J. K. Kay. 2015. Effects of precalving body condition score and prepartum feeding level on production, reproduction, and health parameters in pasture-based transition dairy cows. J. Dairy Sci. 98:7164-7182. https://doi.org/ 10.3168/jds.2014-9269.

Roche, J. R., A. J. Sheahan, L. M. Chagas, D. Blache, D. P. Berry, and J. K. Kay. 2008. Long-term infusions of ghrelin and obestatin in early lactation dairy cows. J. Dairy Sci. 91:4728-4740. https:// doi.org/10.3168/jds.2008-1193.

Roche, J. R., L. R. Turner, J. M. Lee, D. C. Edmeades, D. J. Donaghy, K. A. Macdonald, J. W. Penno, and D. P. Berry. 2009b. Weather, herbage quality and milk production in pastoral systems. 2. Temporal patterns and intra-relationships in herbage quality and mineral concentration parameters. Anim. Prod. Sci. 49:200-210. https: //doi.org/10.1071/EA07308.

Roche, J. R., S. P. Washburn, D. P. Berry, D. J. Donaghy, and B. Horan. 2017b. Seasonal pasture-based dairy production systems.
Large Dairy Herd Management. 3rd ed. D. K. Beede, ed. American Dairy Science Association.

Satter, L. D., and J. R. Roche. 2011. Feed Ingredients | Feed Supplements: Macrominerals. 2nd ed. J. W. Fuquay, ed. Academic Press Inc.

Skrzypczak, W., A. Kurpinska, L. Stanski, and A. Jarosz. 2014. Sodium, potassium and chloride homeostasis in cows during pregnancy and first months of lactation. Acta Biol. Cracoviensia Ser. Zool. 55:58-64.

Sordillo, L. M., G. A. Contreras, and S. L. Aitken. 2009. Metabolic factors affecting the inflammatory response of periparturient dairy cows. Anim. Health Res. Rev. 10:53-63. https://doi.org/10.1017/ S1466252309990016.

Spaans, O. K., B. Kuhn-Sherlock, J. R. Roche, A. Hickey, M. A. Crookenden, A. Heiser, C. R. Burke, and C. V. C. Phyn. 2021. Supplementary Material. https://doi.org/10.5281/zenodo.5646637.

Trevisi, E., N. Jahan, G. Bertoni, A. Ferrari, and A. Min uti. 2015. Pro-inflammatory cytokine profile in dairy cows: Consequences for new lactation. Ital. J. Anim. Sci. 14:285-292. https://doi.org/10 .4081/ijas.2015.3862.

Trevisi, E., F. Piccioli-Cappelli, and P. Grossi. 2010. An additional study on the relationship between the inflammatory condition at calving time and net energy efficiency in dairy cows. Wageningen Academic Publishers.

Turk, R., O. Podpečan, J. Mrkun, M. Kosec, Z. Flegar-Meštrić, S. Perkov, J. Starič, M. Robić, M. Belić, and P. Zrimšek. 2013. Lipid mobilisation and oxidative stress as metabolic adaptation processes in dairy heifers during transition period. Anim. Reprod. Sci. 141:109-115. https://doi.org/10.1016/j.anireprosci.2013.07.014.

Vailati-Riboni, M., M. Kanwal, O. Bulgari, S. Meier, N. V. Priest, C. R. Burke, J. K. Kay, S. McDougall, M. D. Mitchell, C. G. Walker, M. Crookenden, A. Heiser, J. R. Roche, and J. J. Loor. 2016. Body condition score and plane of nutrition prepartum affect adipose tissue transcriptome regulators of metabolism and inflammation in grazing dairy cows during the transition period. J. Dairy Sci. 99:758-770. https://doi.org/10.3168/jds.2015-10046.

Vailati Riboni, M., S. Meier, N. V. Priest, C. R. Burke, J. K. Kay, S. McDougall, M. D. Mitchell, C. G. Walker, M. Crookenden, A. Heiser, J. R. Roche, and J. J. Loor. 2015. Adipose and liver gene expression profiles in response to treatment with a nonsteroidal antiinflammatory drug after calving in grazing dairy cows. J. Dairy Sci. 98:3079-3085. https://doi.org/10.3168/jds.2014-8579.

Watford, M. 2003. The urea cycle: Teaching intermediary metabolism in a physiological setting. Biochem. Mol. Biol. Educ. 31:289-297. https://doi.org/10.1002/bmb.2003.494031050249.

\section{ORCIDS}

O. K. Spaans ๑ https://orcid.org/0000-0002-8622-5301

B. Kuhn-Sherlock () https://orcid.org/0000-0002-1890-0301

M. A. Crookenden (๑) https://orcid.org/0000-0002-6137-2006

A. Heiser $\odot$ https://orcid.org/0000-0003-0389-6132

C. R. Burke () https://orcid.org/0000-0003-3868-8675

C. V. C. Phyn ๑ https://orcid.org/0000-0002-4912-4069

J. R. Roche 구 https://orcid.org/0000-0002-4165-9253 